\title{
هستوى قلق الإحصاء لدى طلبة الدراسات العليا في كلية التربية وعلاقته ببعض المتغيرات
}

إعداد

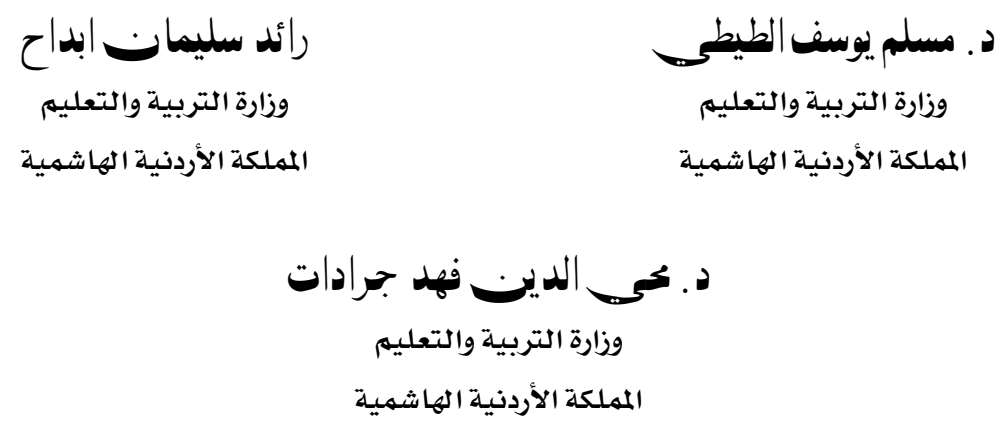

مجلة بحوث التربية النوعية ـ جامعة المنصورة

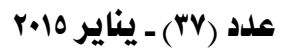




\section{هستوى قلق الإحصاء لدى طلبة الدراسات العليا في كلية التربية وعلاقته ببعض المتغيرات}

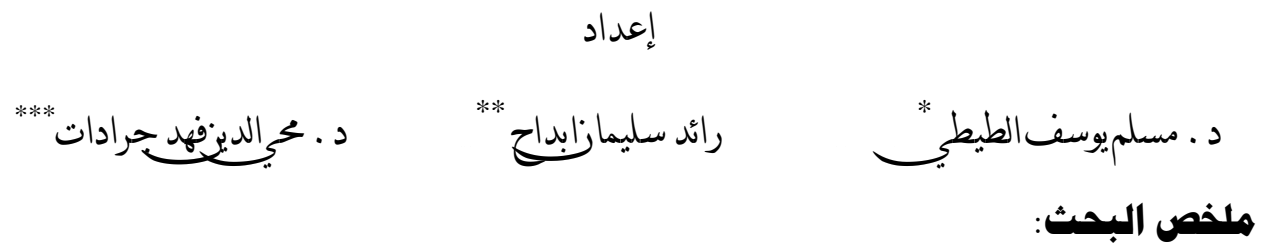

هدفت هـذه الدراسـة إلى التعـرف على مستوى قلق الاحصـاء لـدى طلبـة الدراسـات العليـا ِِِ

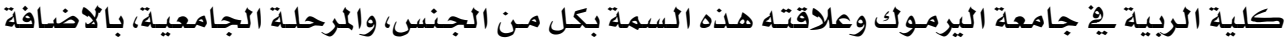

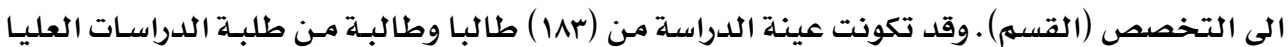

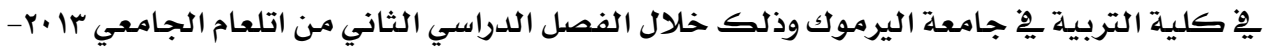

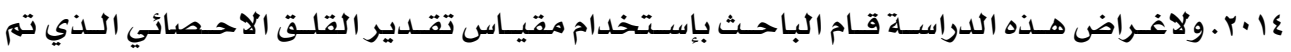

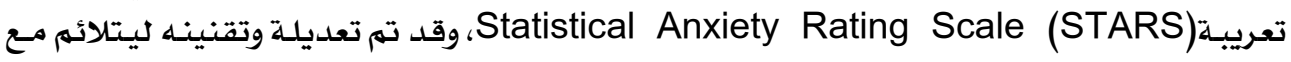
البيئة الاردنية حيث تم تطبيقه، بصورته النهائية والتي تضمنت (؟ ع) فقرة.

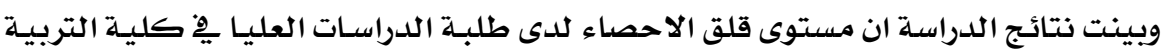

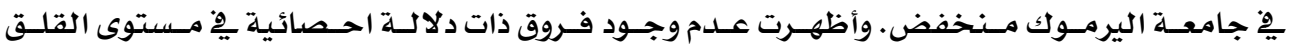

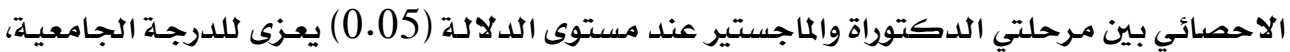

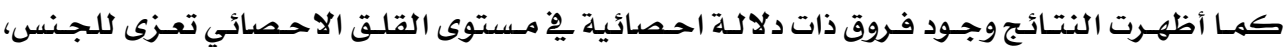

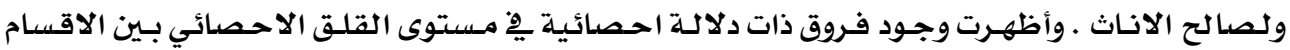

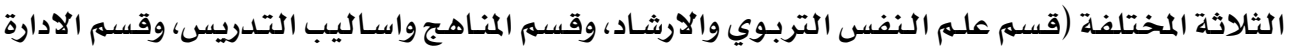
التربوية واصول التربية) وذلك لصالح قسم الادارة التربوية واصول التربية التربية.

همبدمة

يعتبر القلق Anxiety مـن المشكلات الشائعة الظهـور لـدى الكثير مـن الافراد حيـث تتعـدد

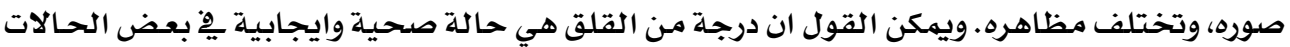

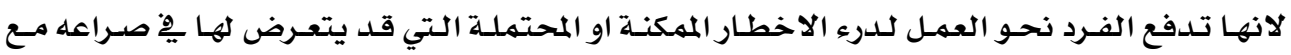

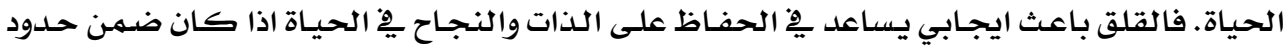

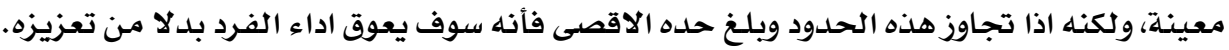

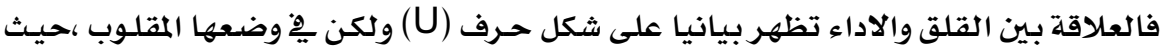

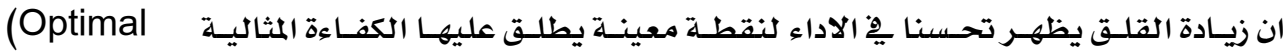




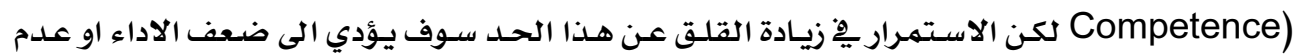
القدرة على الانجازونقص مستوى الكفاءة (Keable, 1997).

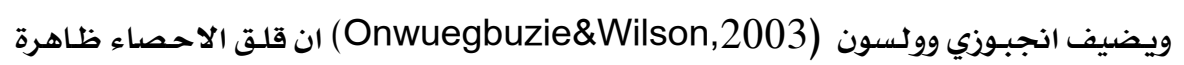

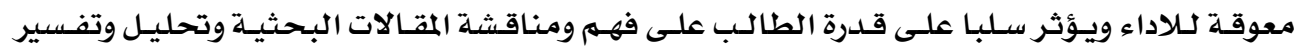

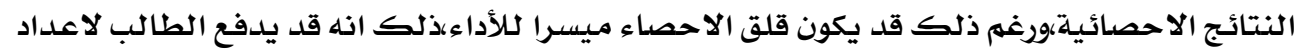

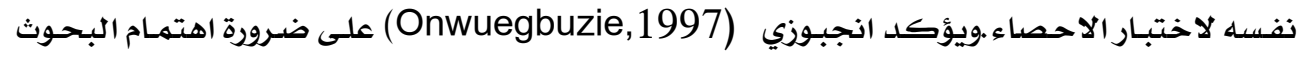

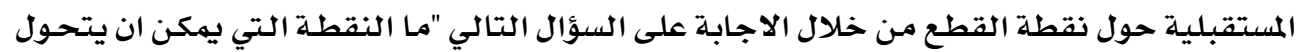

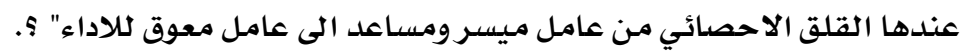

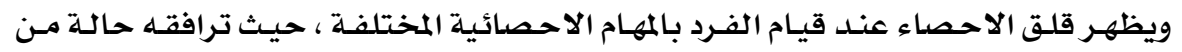

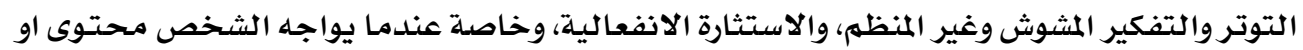

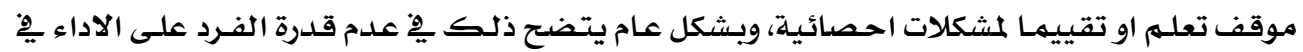

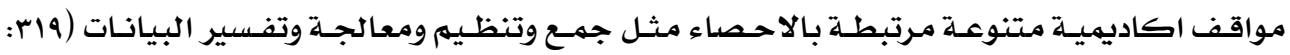
- (Zinder, 1991

ويـرى انجبـوزي وويلسون (Onwuegbuzie \& Wilson, 2003 ) ان تعلـم الاحصـاء

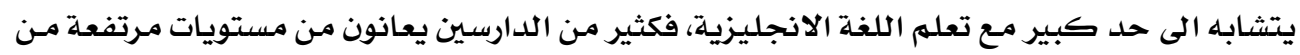

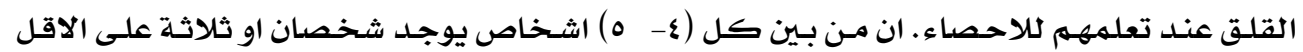

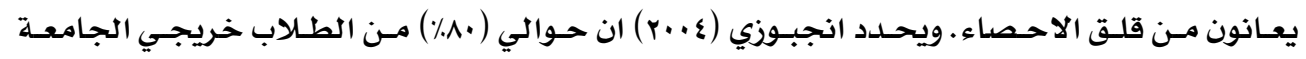

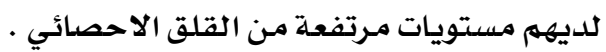

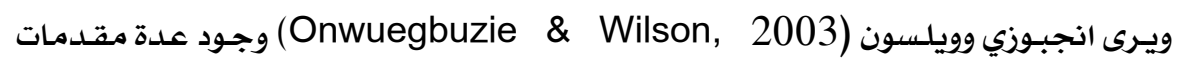

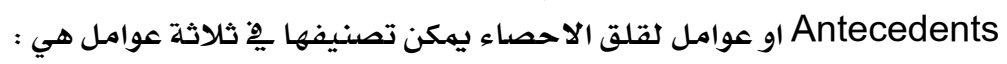
(أ) عوامل موقفية Situational Factors

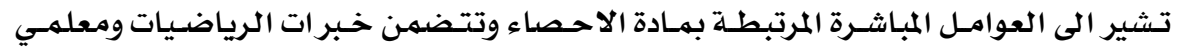

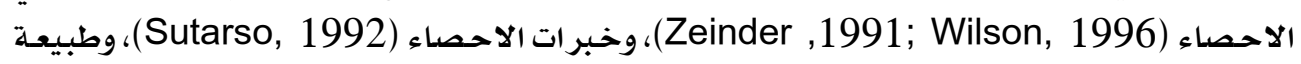

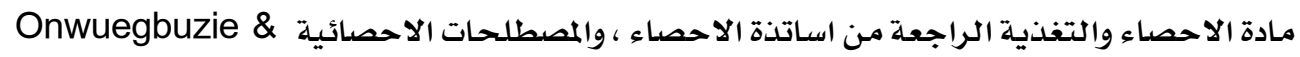
.(et al, 1997)

واظهرت نتائج دراسة بان وتانج (Pan \& Tang, 2004) وجود ارتباط سالب دال احصائيا

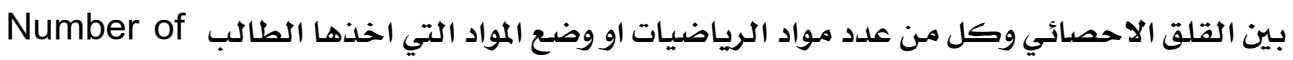

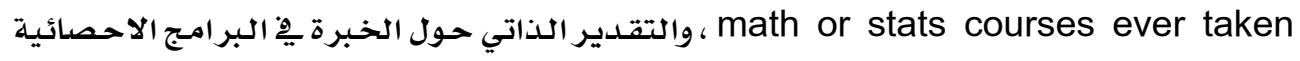

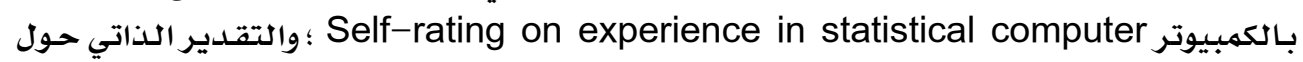
الخبرة يِّ البحث الاكاديهي Self-rating on experience in academic research. 
(ب) عوامل نقسية Dispositional Factors

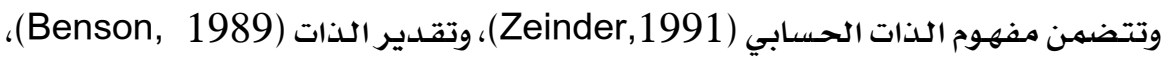

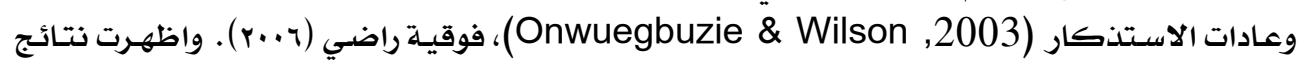

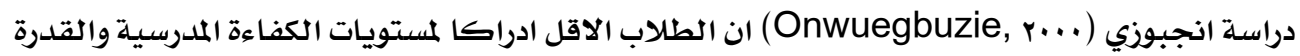
العقلية والابتكاريـة يميلون الى الشعور بمستويات مرتفعة من القلق الاحصائي.

(ج) عوامل شخصية Personal Factors:

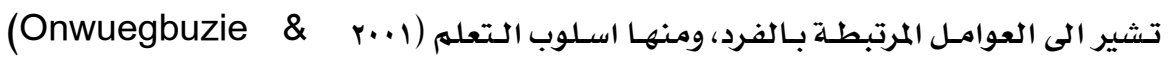

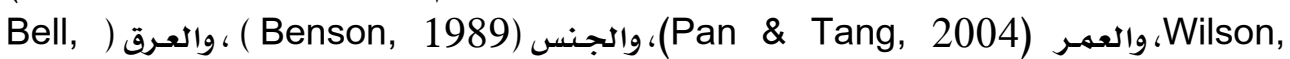
.)(2004

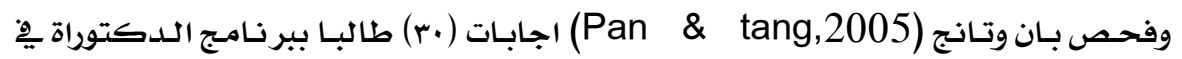

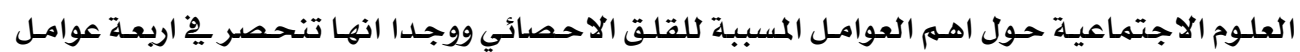

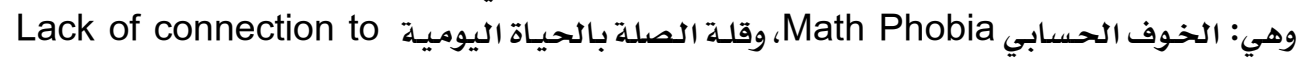

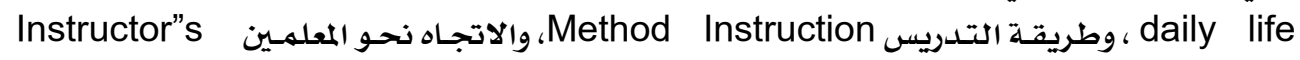
.attitude

وتوصل كولينس وانجبـوزي (Collins \& Onwuegbuzie, 2007) الى وجـود ارتبـاط

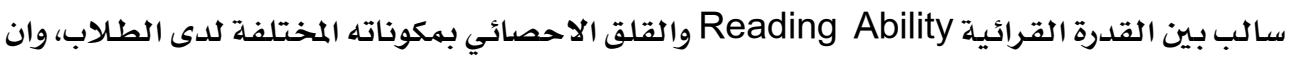

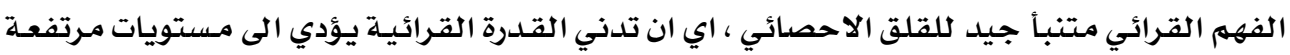
من القلق الاحصائي.

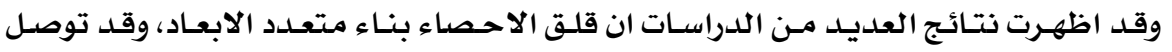
كروزوآخرون (Cruise \& et al, 1985) الى ستة مكونات لقلق الاحساء العصاء :

\section{اولا : قيمة الاحصاء Worth of Statistics:}

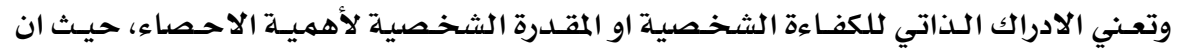

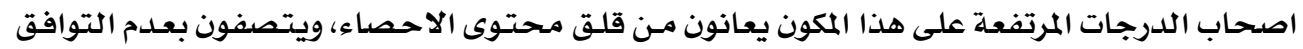

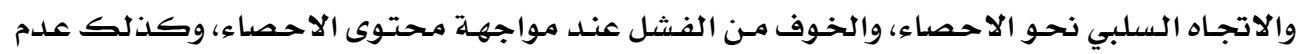

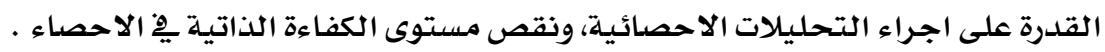
ثانيا : قلق التفسير Interpretation Anxiety

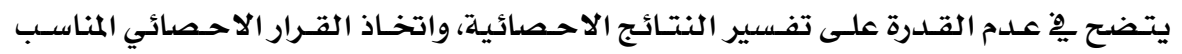

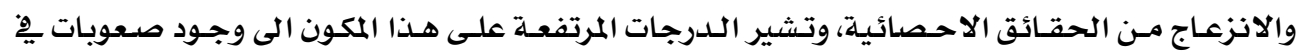

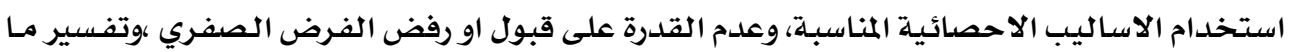
يلدور من احداث يومية احصائية. 


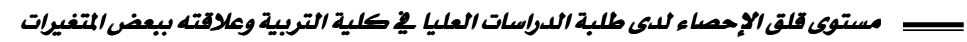

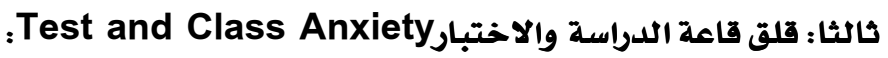

$$
\text { ينقسه هذا المكون الى نوعين: }
$$

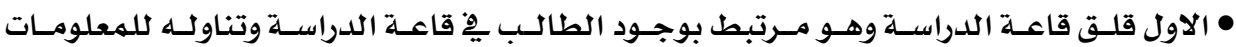

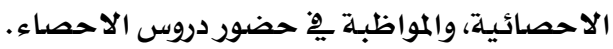

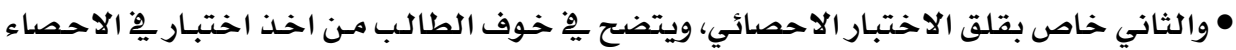

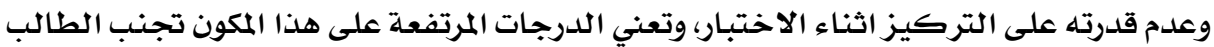

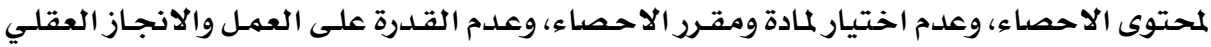

فيه .

رابعا : مفهوم الذات الحسابي Computation Self -Concept

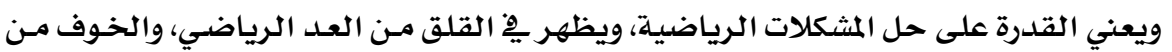

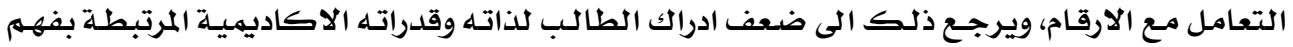

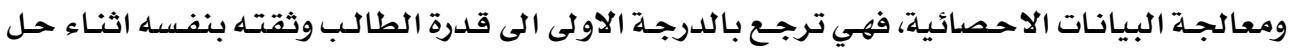

المثكلات الرياضية.

بغض النظر عن اتجـاهـه نحوهـا، ويتصف اصـحاب الدـرجات المرتفعـة على هـذا المكـون بعـدم

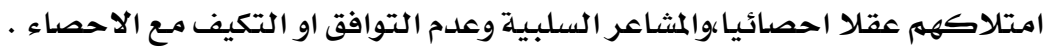

خامسا : الخوف من طلب المساعدة Fear of asking Help؛

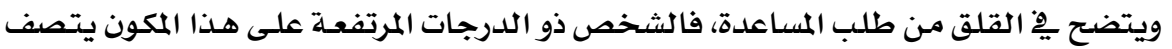

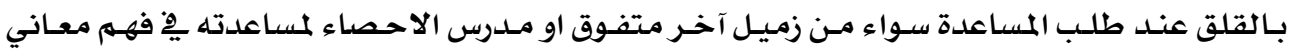

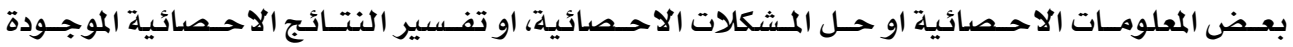

سادسا : الخوف من اساتذة الاحصاء Fear of Statistics Teachers:

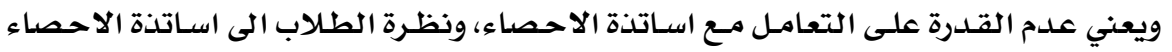

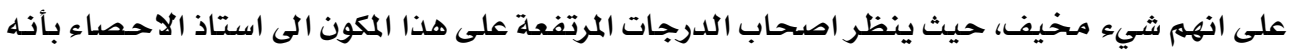

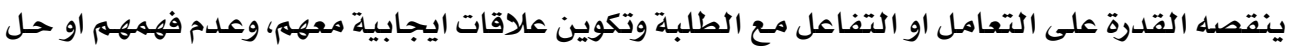

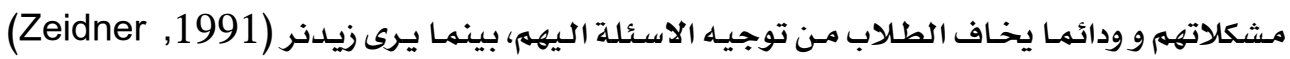
وجود مكونين للقلق الاحصائي:

• الاول: قلق المحتوى الاحصائي Statistic Content Anxiety ويعني خوف الفرد مـن مواجهـة

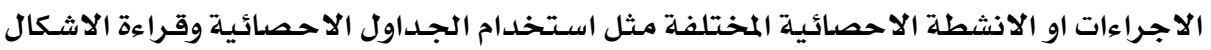

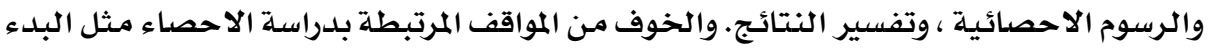

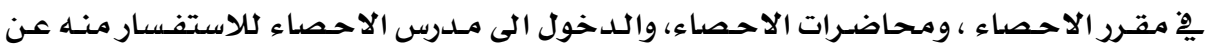
موضوعات احصائية . 


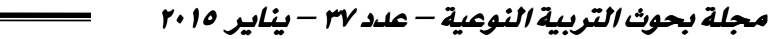

• الثاني: قلق الاختبار الاحصائي Statistics Test Anxiety: ويتضح ِِِ الانزعاج والاضطراب

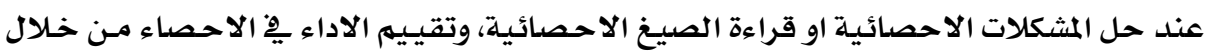

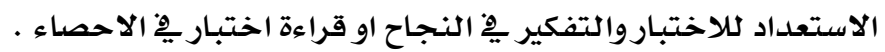

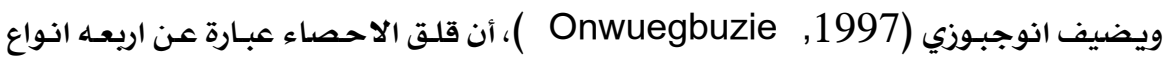

الفائدة المدركة للاحسـاء Perceived usefulness of Statistic وترتبط بكيفيـة

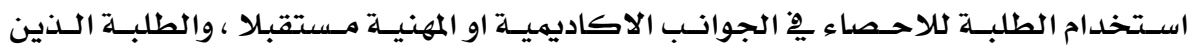

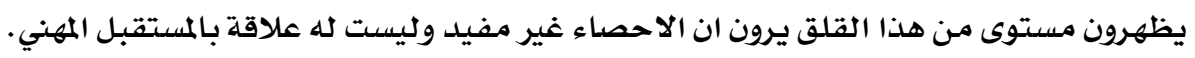

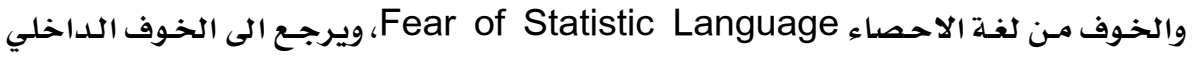

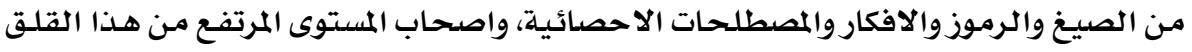

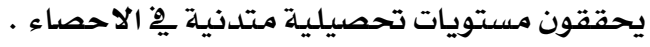

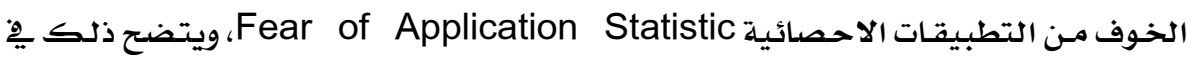

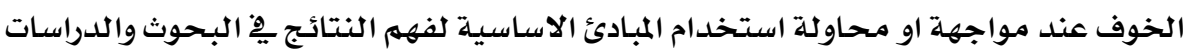

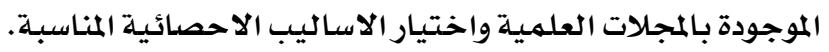

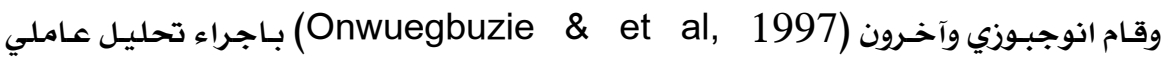

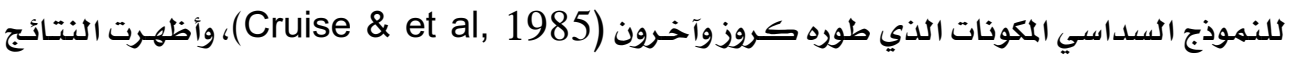

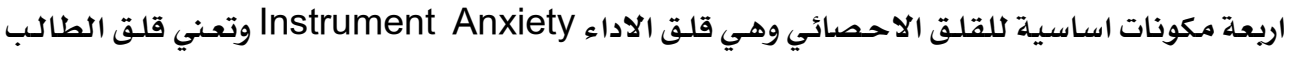

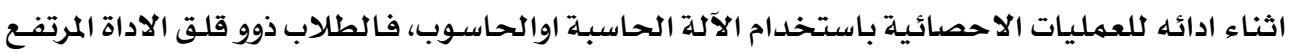

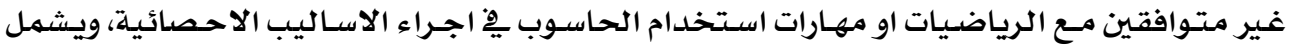

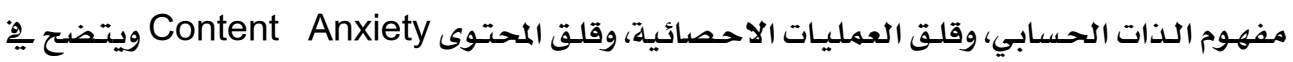

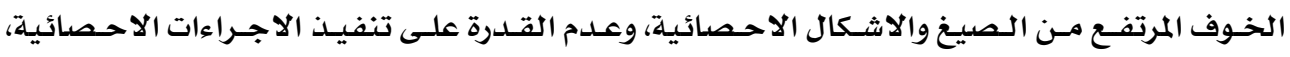

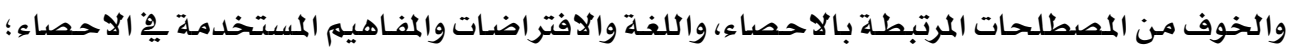

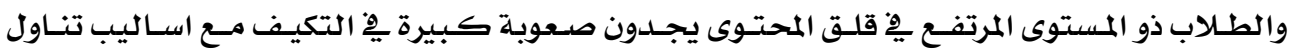

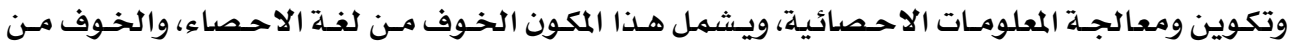

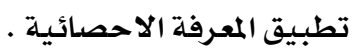

القلق البينشخصي Interpersonal Anxiety ويمثل المكون الثالث، والذي يتضح هِّ الخـوف

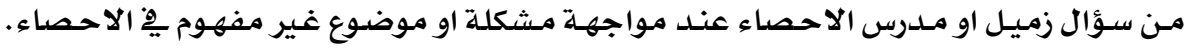

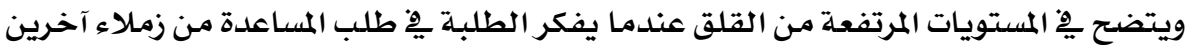

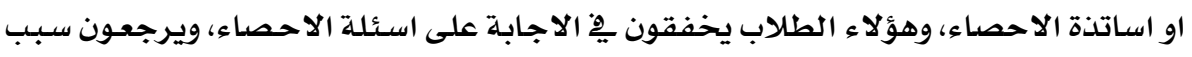

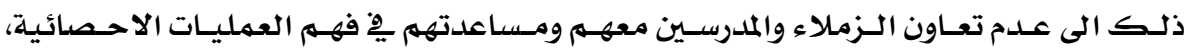
ويشمل هذا المكون الخوف من طلب المساعدة، والخوف من مدرسي الاحصاء. 


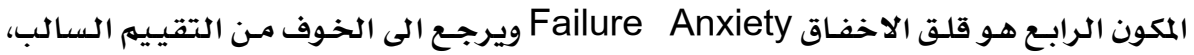

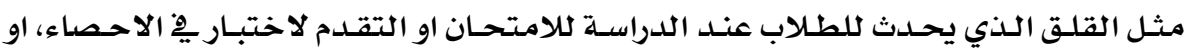

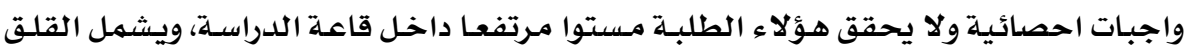

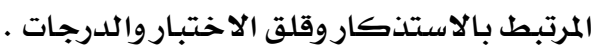

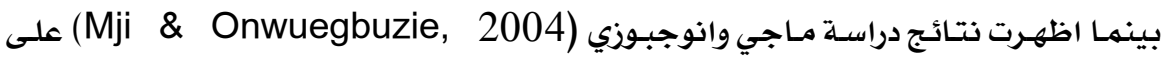

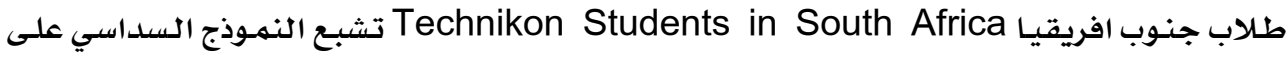

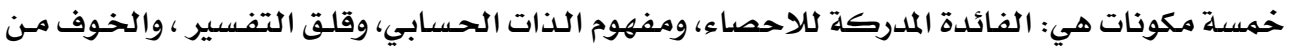

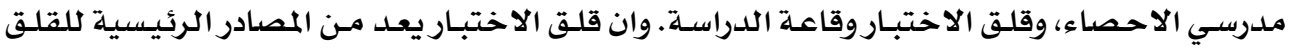

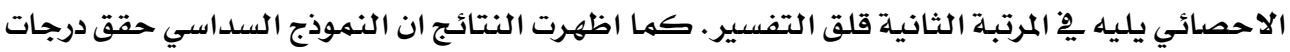

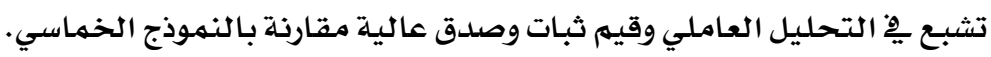

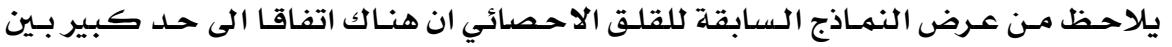

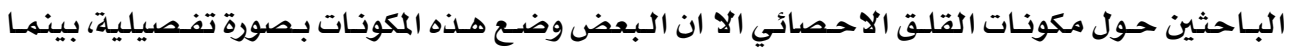

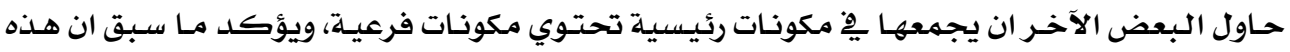

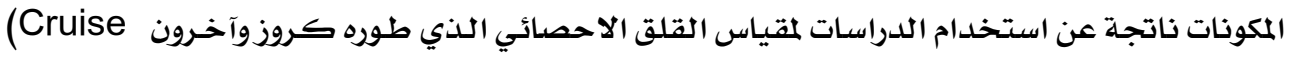
\& et al ,1985) لقد تركزت البحوث والدراسـات حول القلق العـام (General Anxiety) لفترة طويلـة. الا

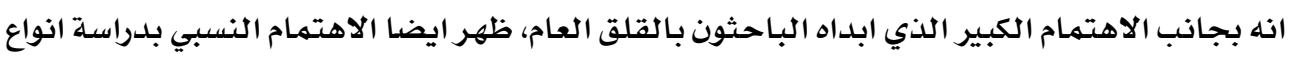

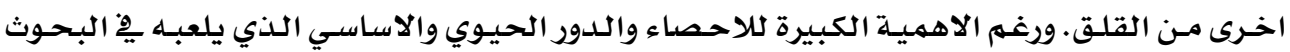

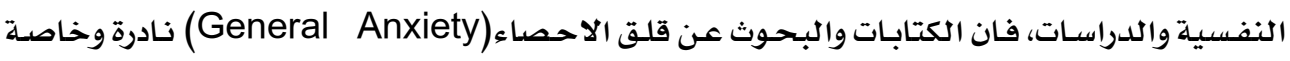

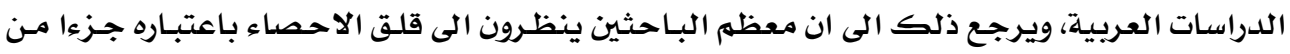

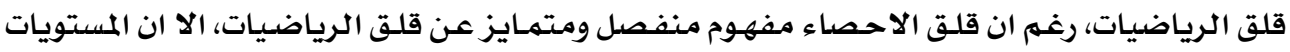

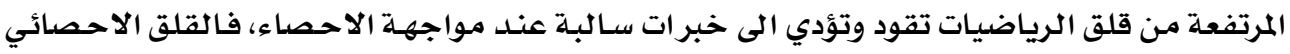

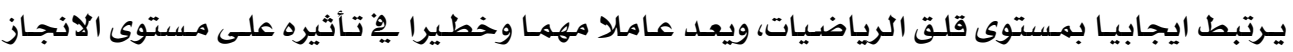
الاكاديهي، والطمـوح المهني لـدى الطلاب (Onwuegbuzie, 1997).

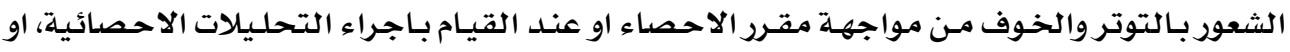

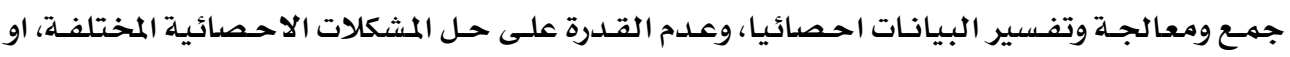
اتخاذ القرارات الاحصائية المناسبة (Bradstreet, 1996).

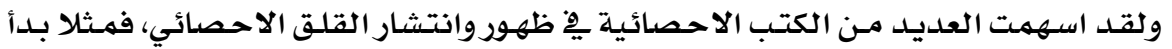

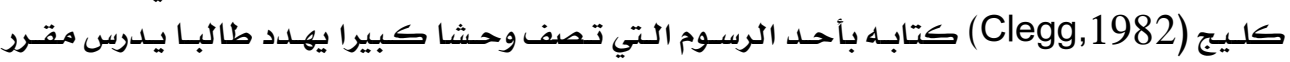

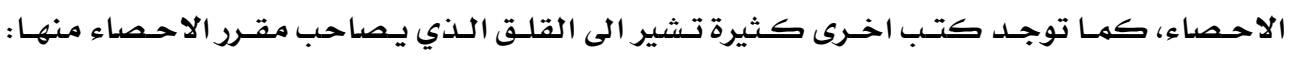

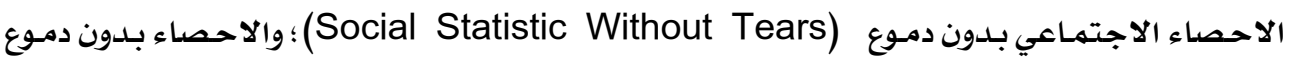
(What S Funny about (Statistic Without Tears) 
$\underline{\underline{2}}$

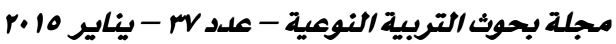

Technique For Reducing Student وتقنية (Statistic)

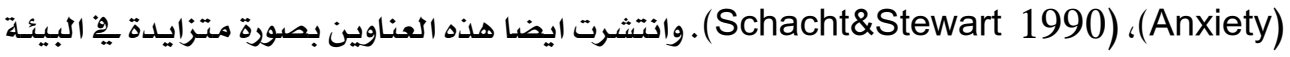

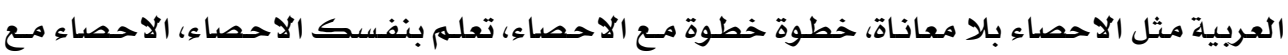

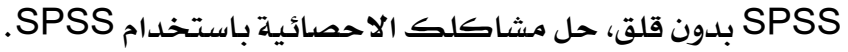
ويرى ولسون وانجبـوزي (Onwuegbuzie\&Wilson,2001) ان العوامـل المسببة للقلـق

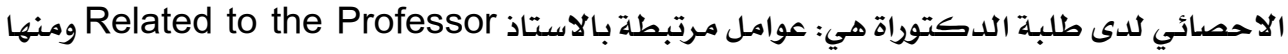

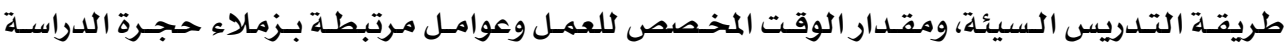

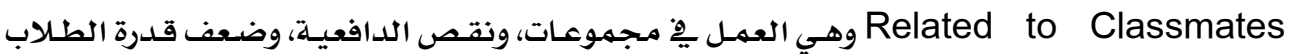

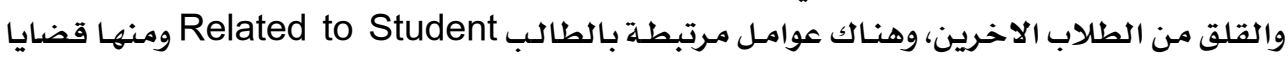

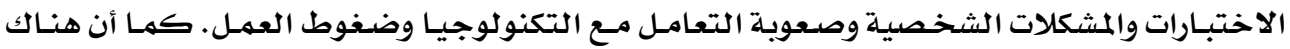

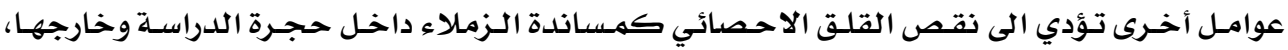

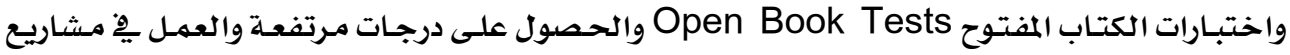

بحثية ضنمن مجهموعات صغيرة.

\section{هشكلة الدراسة وأسئلتها:}

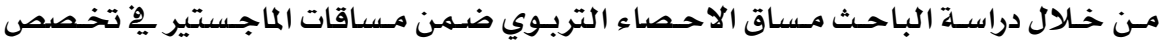

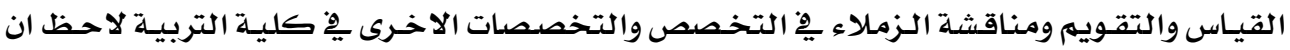

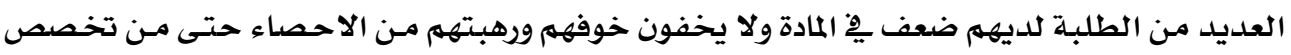

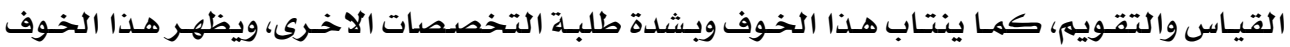

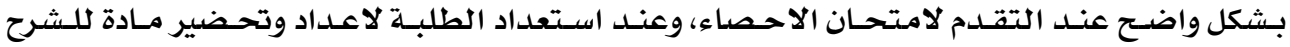
اوتحليل الجداول او رسومات احصائية امـام الطلبة الاخرين.

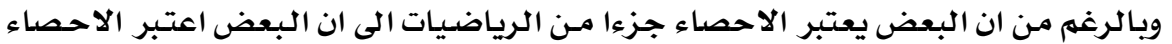

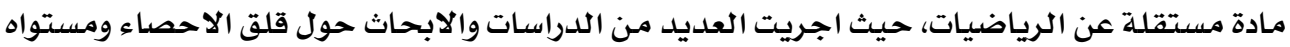

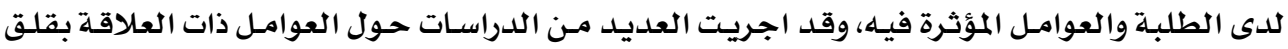

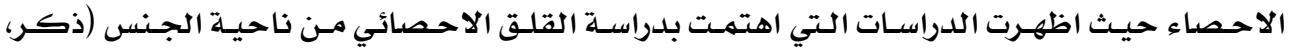

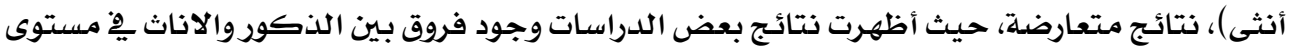

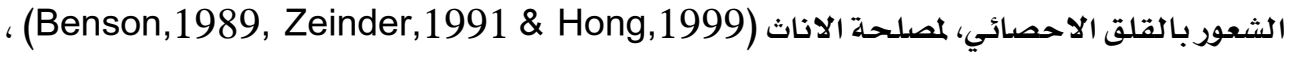

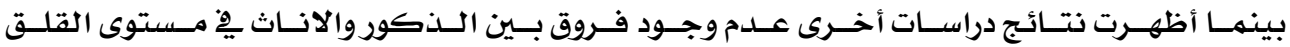
الاحصائي(Sutarso, 1992; Toto, 1992; Trimarco, 1997; Baloglu,2003).

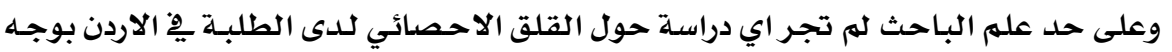

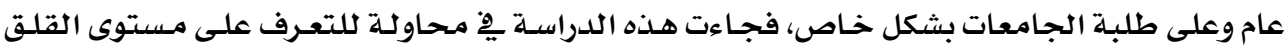

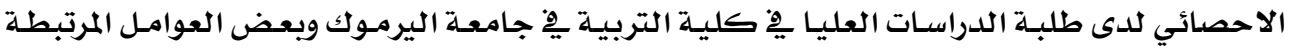

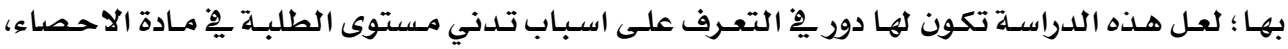




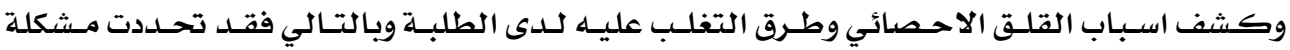
الدراسـة بالسؤال الرئيس التتالي :

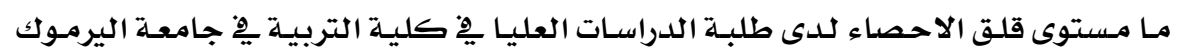
وعلاقته ببعض المتغيرات ؟

ويتفرع من هذا السؤال الاسئلة الفرعية التالية :

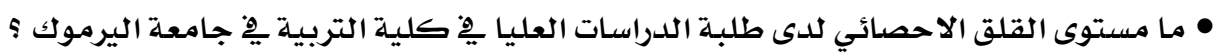
• هل تختلف مستويات القلق الاحصائي لدى الطلبـة باختلاف الجنس (ذكر، أنثى) ؟

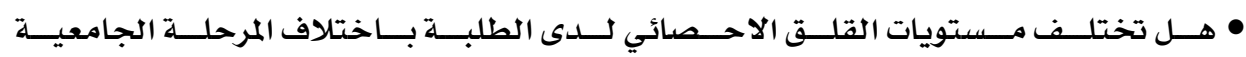
(دكتوراة، ماجستير)

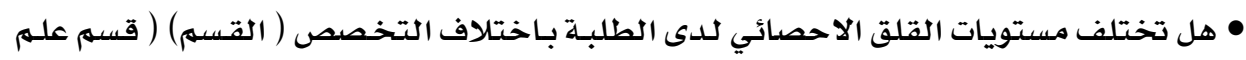
النفس التربوي، قسم المناهج واسـاليب التدريس، قسهم الادارة التربوية واصول التربية )؟

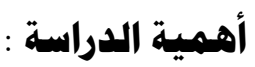

تنبـع اهمية الدراسـة الحالية مـن عدة اعتبارات اهمها: ا- ان مـواد الاحســاء مـن اكثـر المقـررات الدراسـيـة اثـارة لـشـاعر الخـوف والقلـق لـدى طـلاب

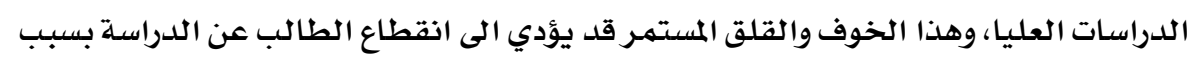
مادة الاحصاء وانهسحابهـ من الدراسـات العليا. ץ- استخدام المقيـاس قد يفيد يِّ الكشف عن مستوى القلق الاحصدائي والعوامـل التي تؤدي الى رفع مستوى القلق عند الطلبـة، مها يسـاعد على محاولة التغلب عليها او التقليل من تأثيرهـا او وضـع برامـج ارثـاديـة وعلاجيـة مناسبـة.

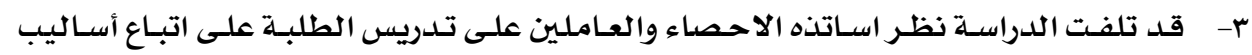
متتنوعة من اجل ازالة الخوف والتوتر مـن مواد الاحصاء لدى الطلبـة.

\section{أهداف الدراسة :}

$$
\text { تهدف الدراسـة الحالية الى تحقيق الاهداف التالية : }
$$

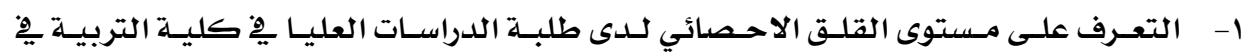

$$
\text { جامعة اليرموك }
$$

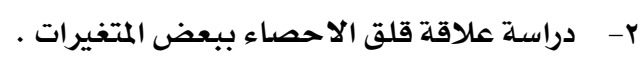

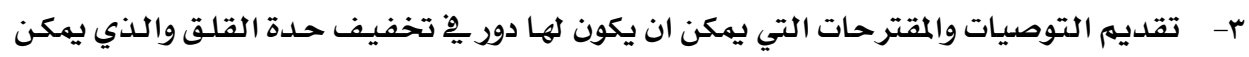
ان يؤدي الى تحسن يخ مستوى اداء الطلبـة يِّ مساقات الاحصاء وتحصيلهم فيها . 


\section{حدود الدراسة:}

تتحدد الدراسة بها يلي:

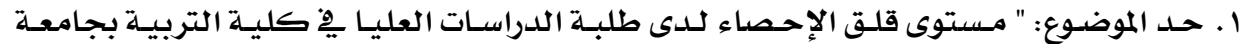

$$
\text { اليرموك وعلاقتته ببعض المتغيرات". }
$$

r ـ الحد المكاني: محافظة اريد ، جامعة اليرموك: كلية التربية.

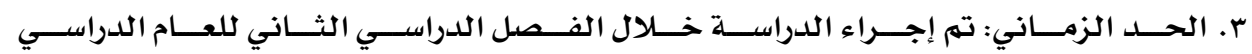

$$
r+1 \varepsilon-r \cdot 1 r
$$

ع ـ الحد البشري: طلبة الدراسات العليا الدكتوراه والماجستير ِِّ كلية التربية، جامعة اليرموك.

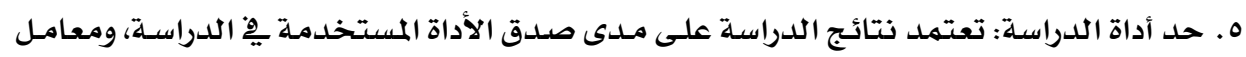

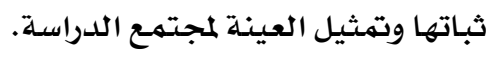

أدوات الدراسة :

مقيـاس القلق الاحصـائي الذي ترجمـه ووعربـه السيد ابـراهيه وطبقه على عينتين سعودية

$$
\text { ومصرية يِ المملكة العربية السعودية. }
$$

هصطات الدراسة:

• القلق الاحصائي Statistic Anxiety :

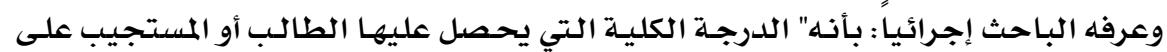

مقياس القلق الاحصائي".

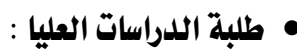

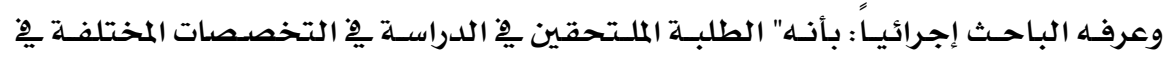

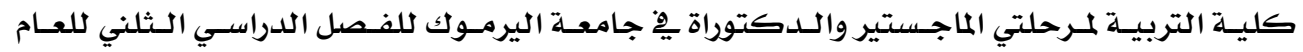
. $(r+1 \varepsilon-r \cdot 1 r$

\section{الدراسات السابقة}

أجـرت بنسون ( Benson,1989) دراسـة هـدفت إلى التعـرف على المكونـات البنائيسة لقلق

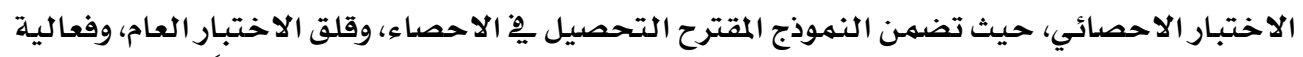

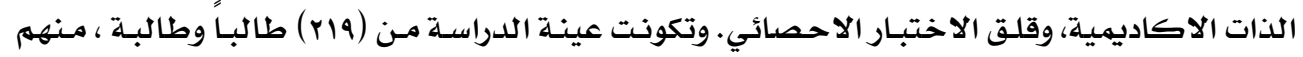

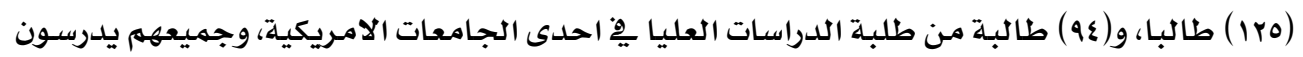

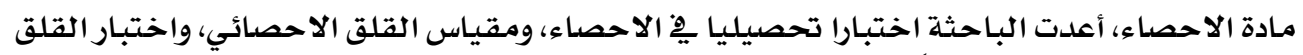

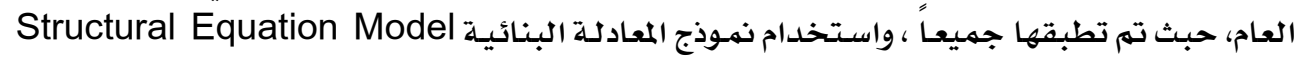

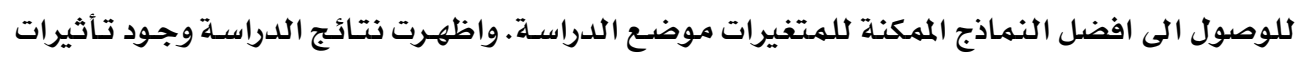

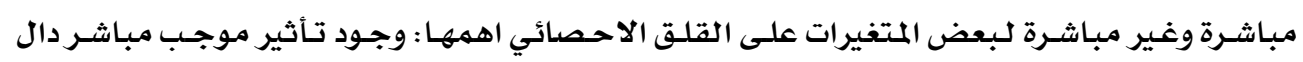




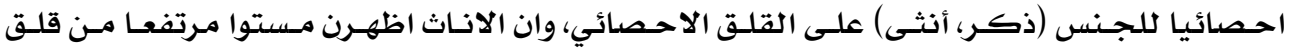

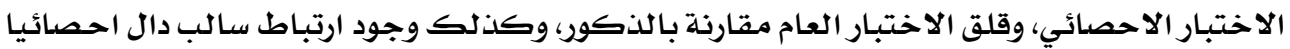

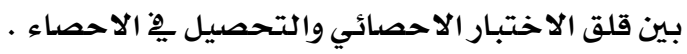

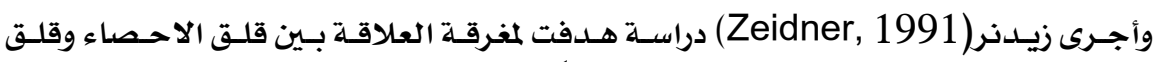

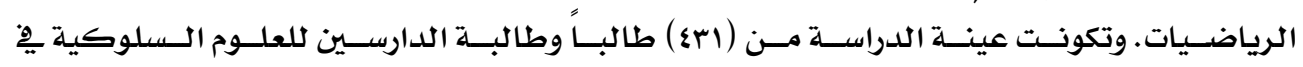

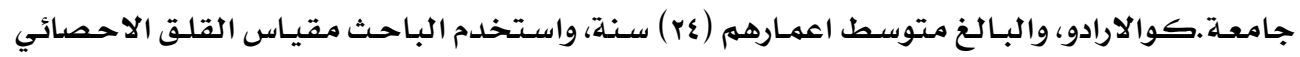

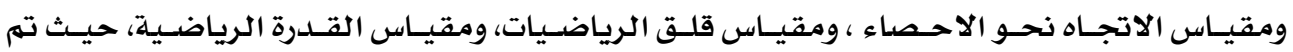

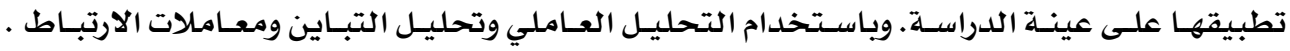

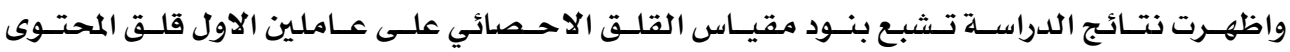

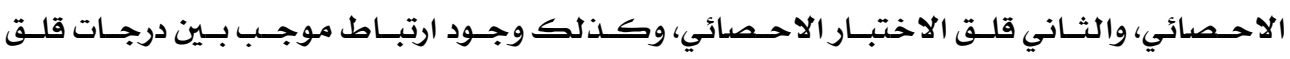

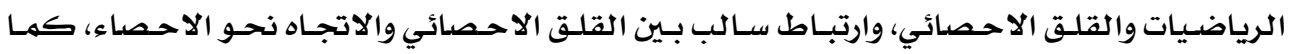

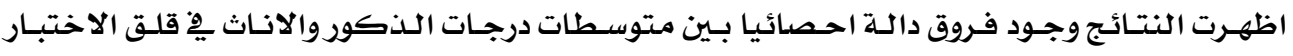

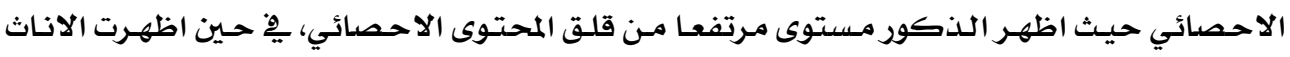
مستوى مـرتفعا من قلق الاختبار الاحصائي.

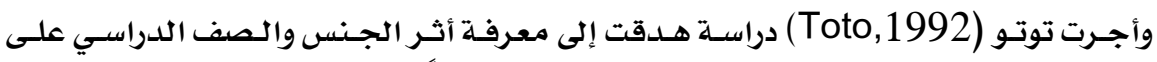

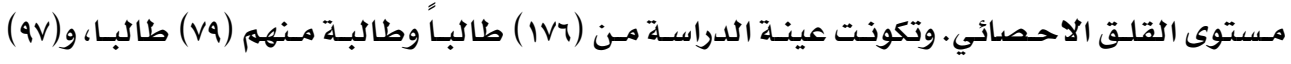

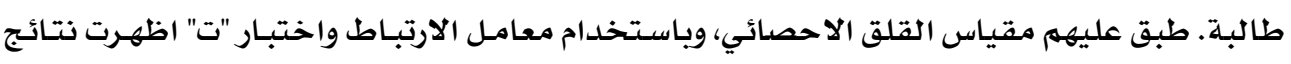

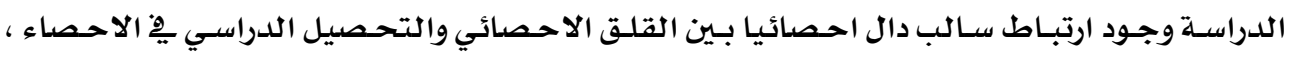

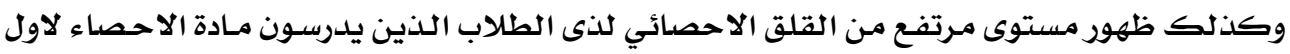

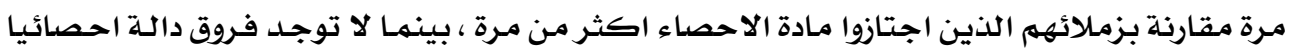

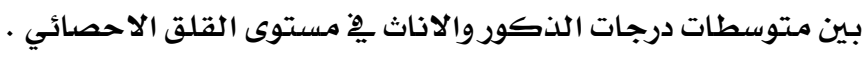

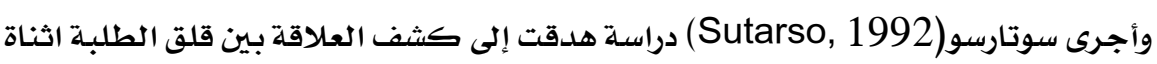

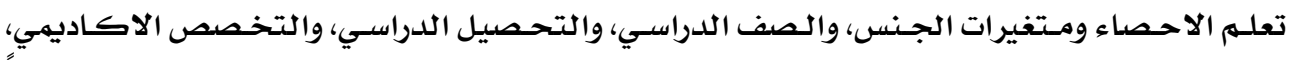

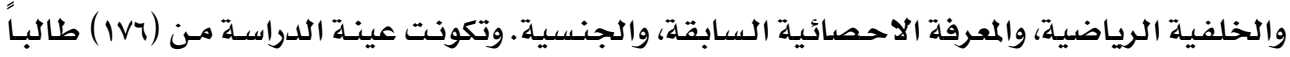

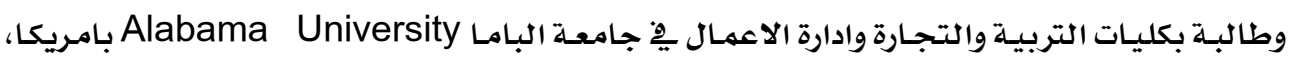

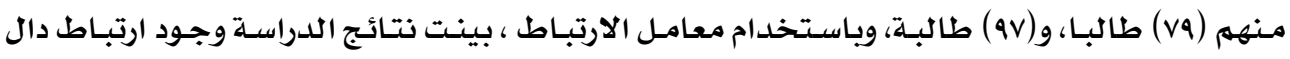

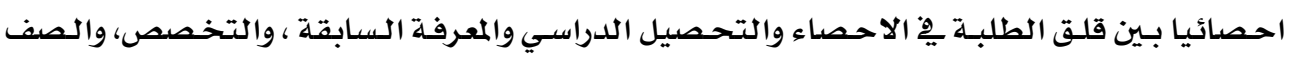

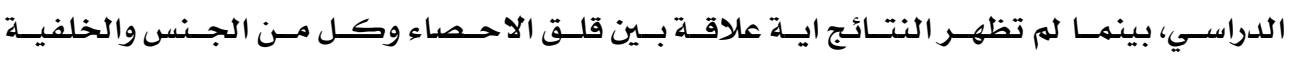
الرياضية والجنسية .

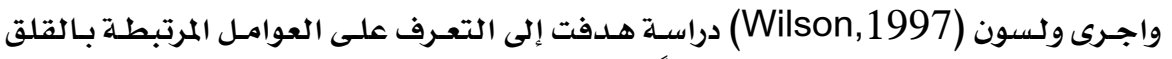

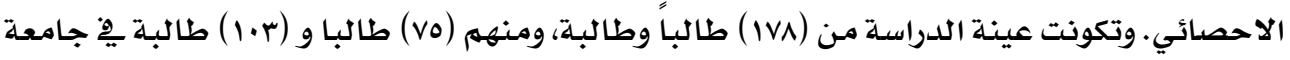

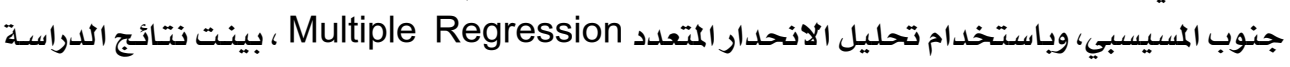




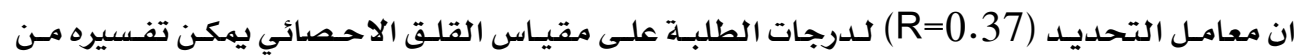

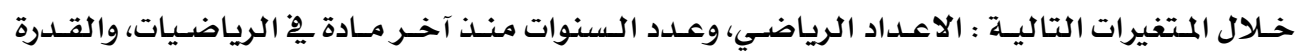

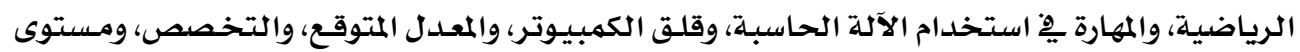

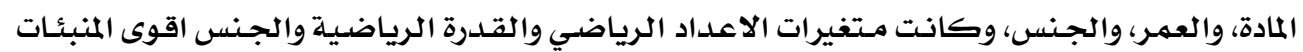
بقلق الاحصاء. وأجرى جـيمس(James, 1998) دراسـة هـدفت الى التعـرف على مستوى القلق الاحصائي

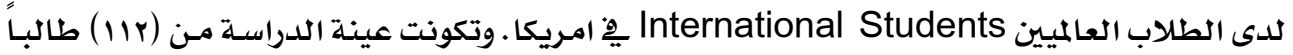

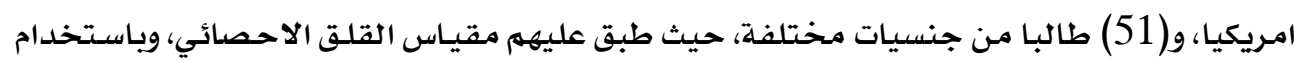

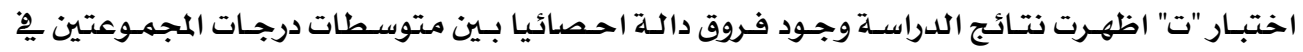

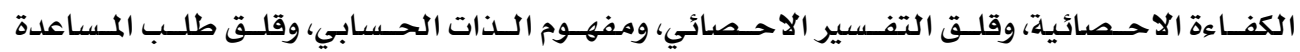

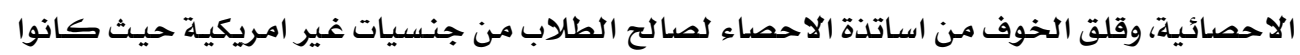

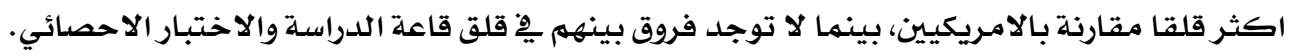

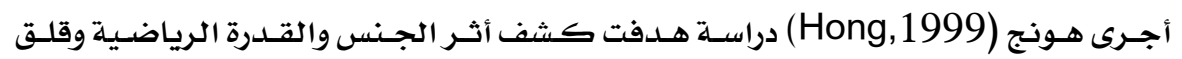

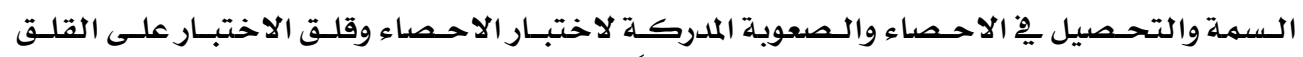

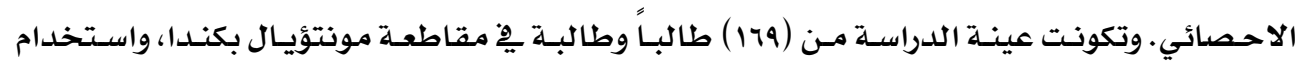

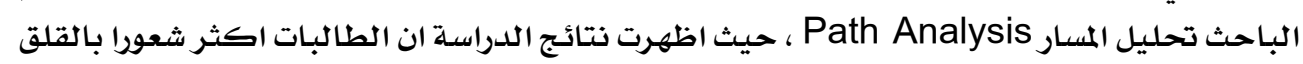

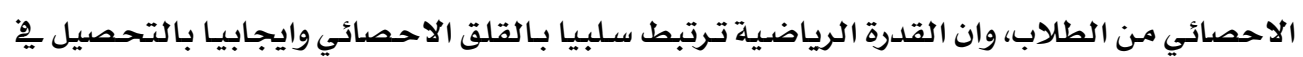

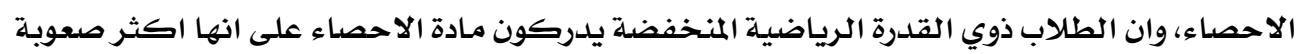

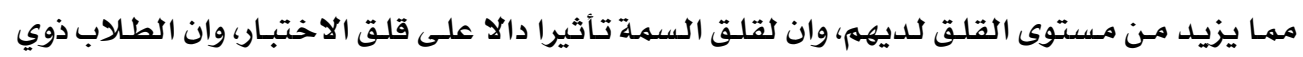

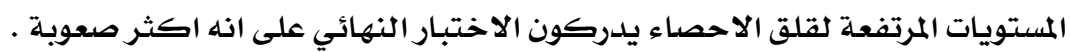

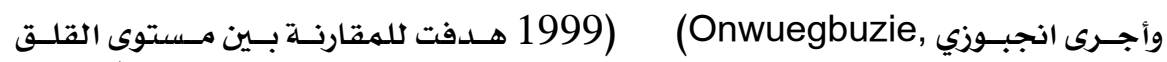

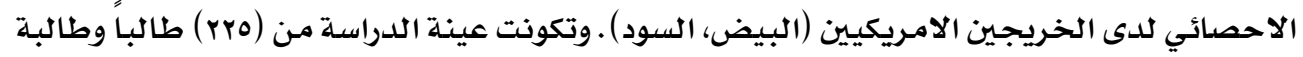

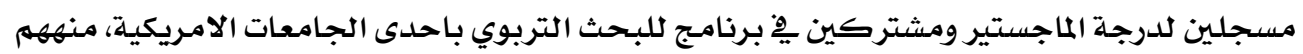

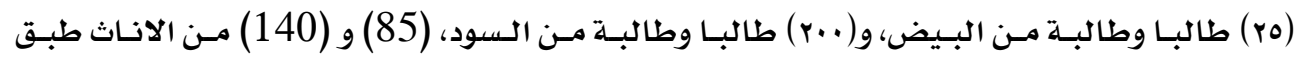

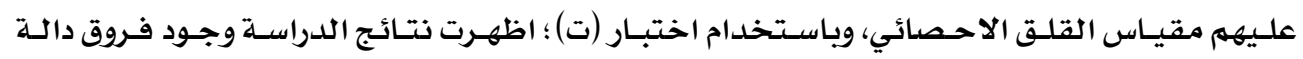

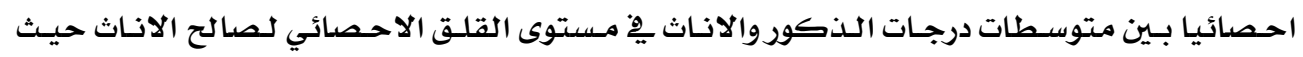

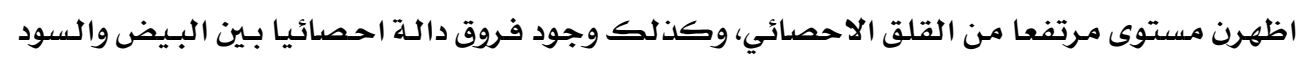

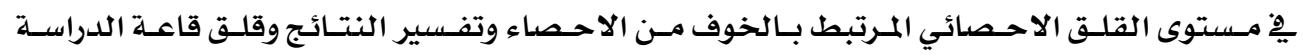

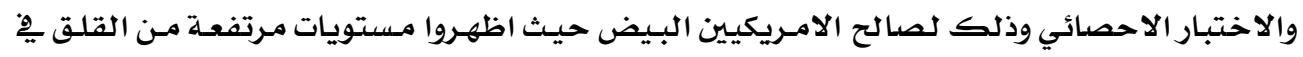

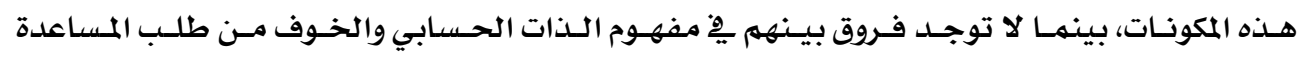

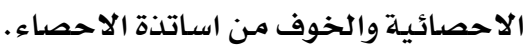




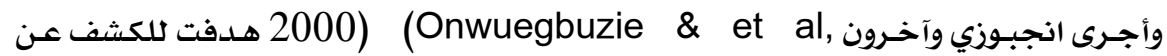

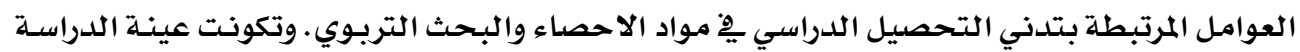

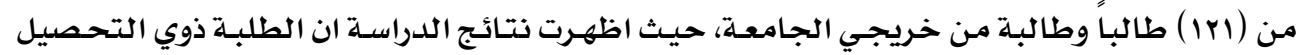

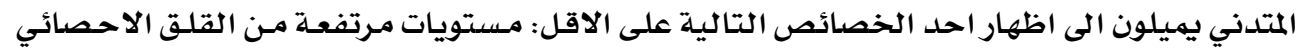

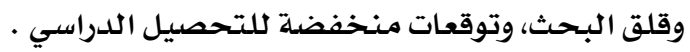

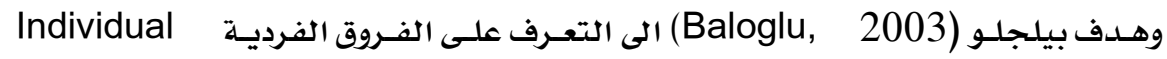
Differences

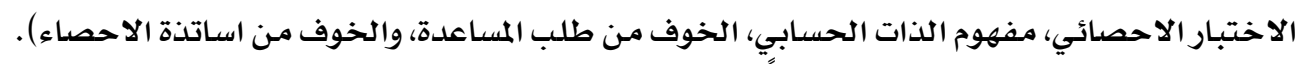

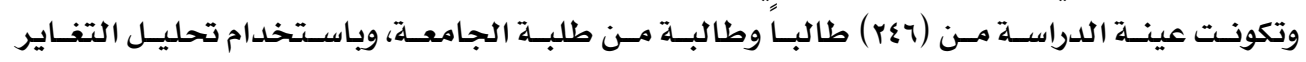
Analysis of Covariance (ANCOVA)

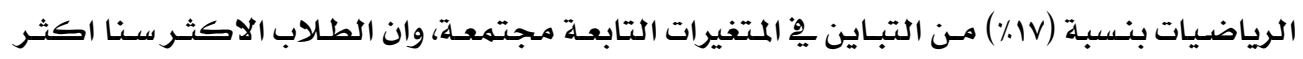

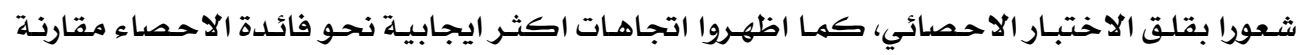

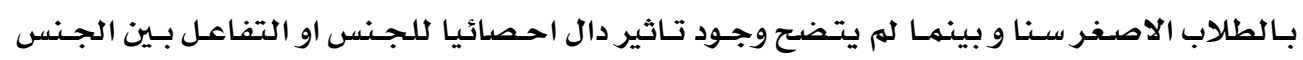
والعمر على درجة شعور الطلبة بالقلق الاحصائي.

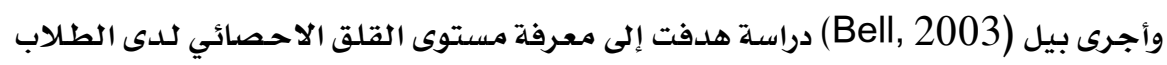

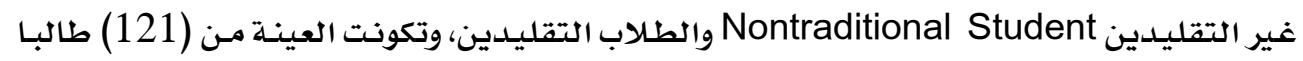

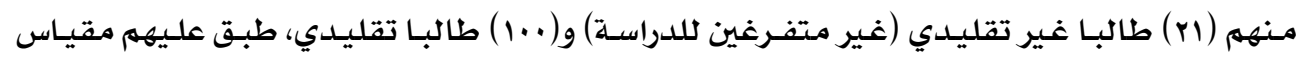

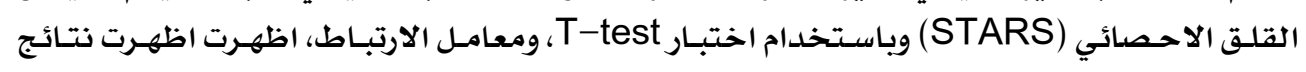

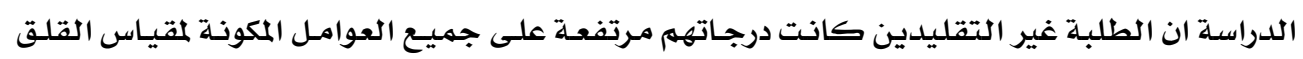

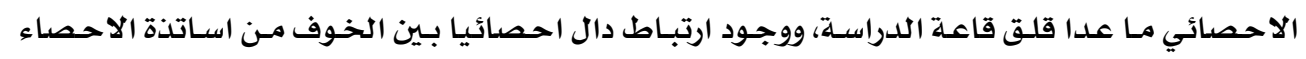

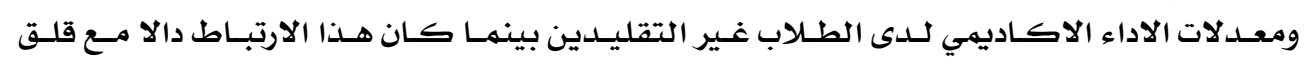

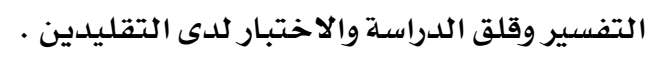

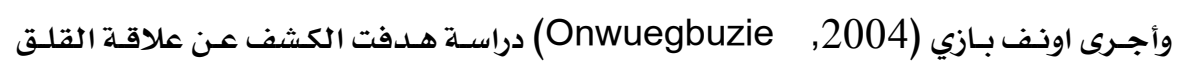

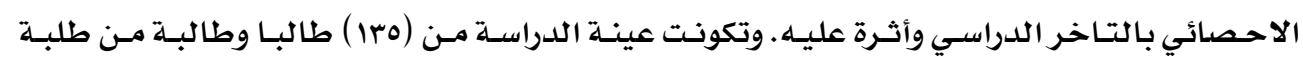

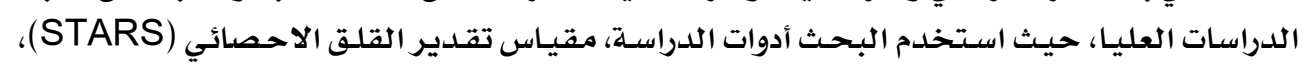

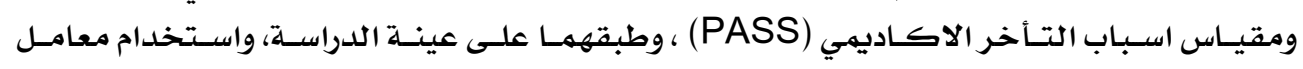

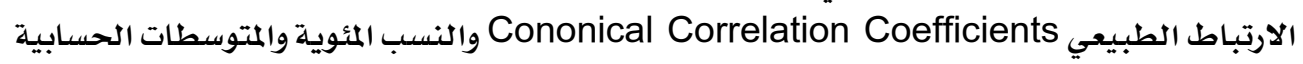

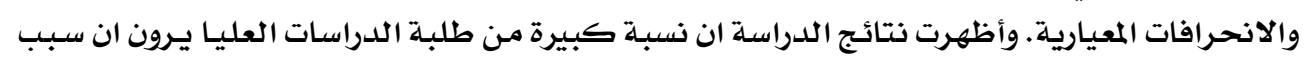

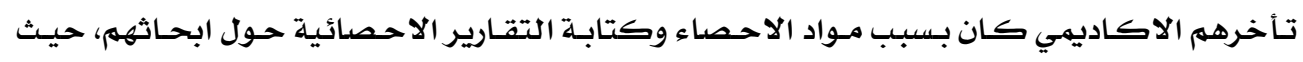

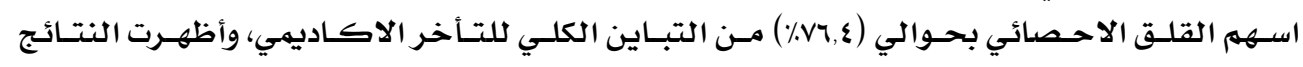

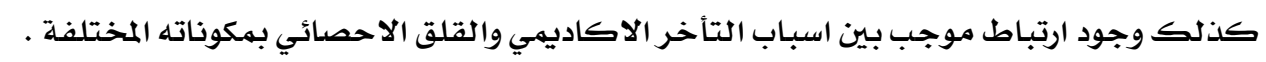




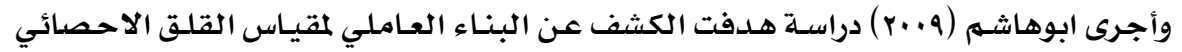

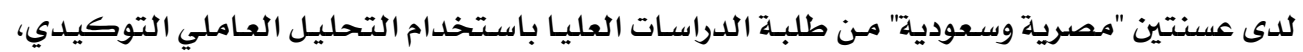

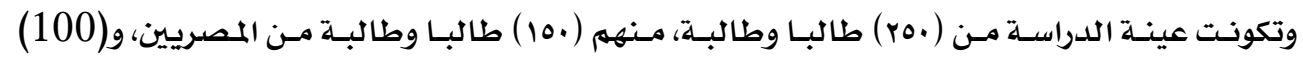

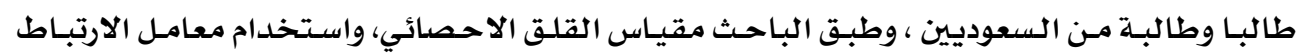

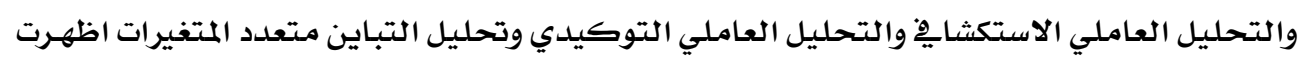

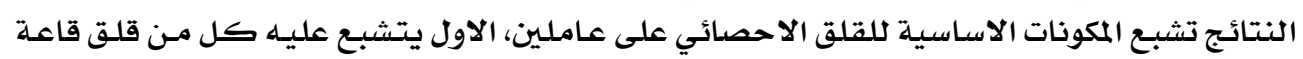

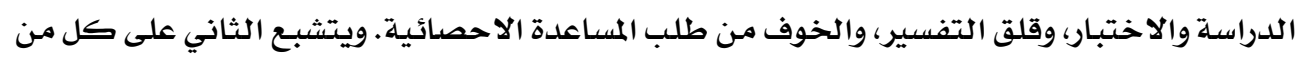

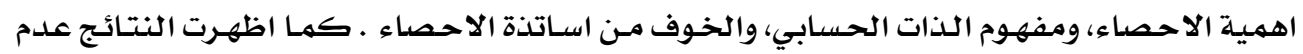

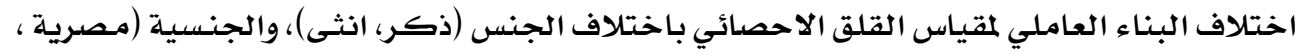

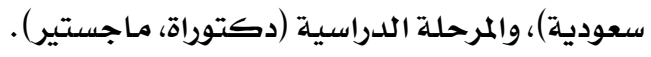

\section{هلخص الدراسات السابقة}

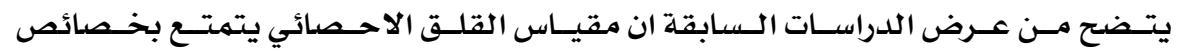

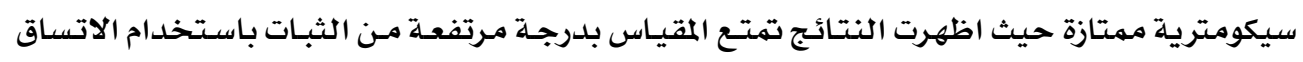

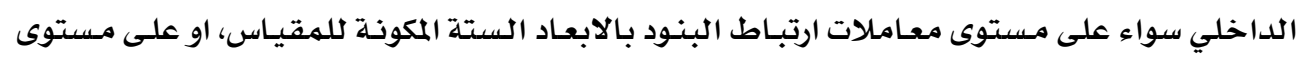

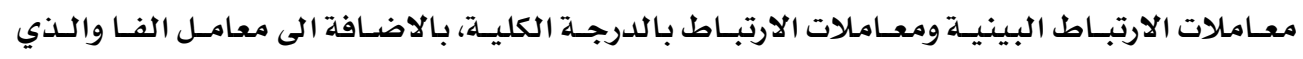

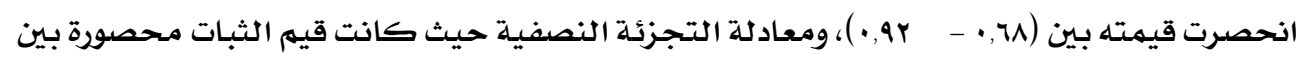

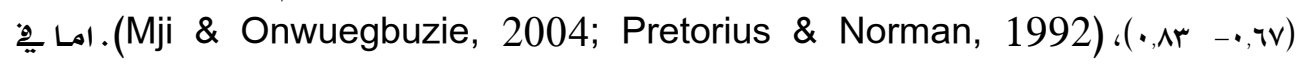

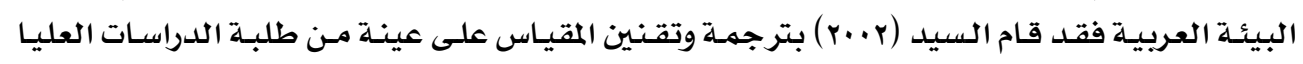

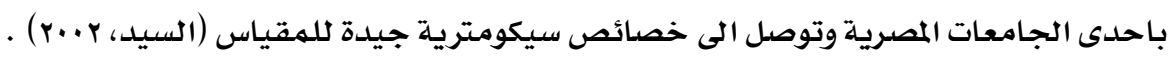

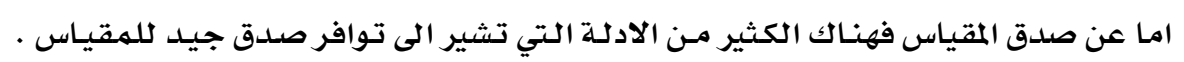

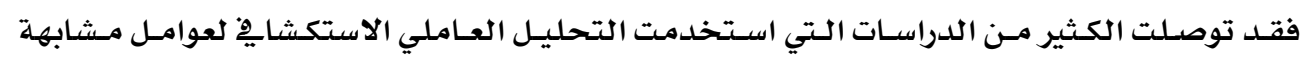

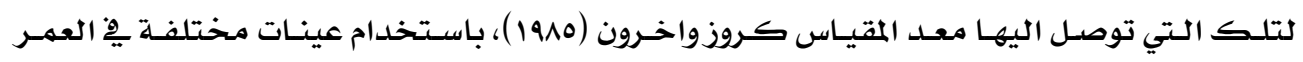
والجنس والجنسية ومستوى التعليم

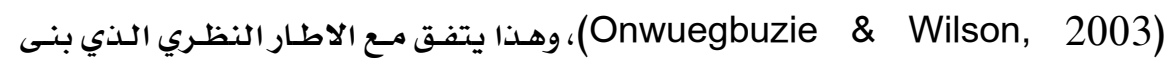

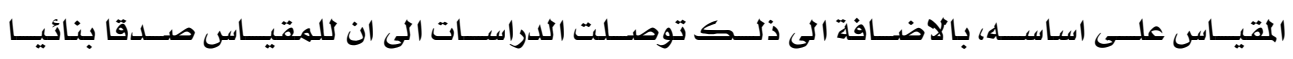
(Onwuegbuzie \& et al, 2003; وكذلك صدقا تمييزيا مرتفعان (Onwuegbuzie, 2003)

Baloglu, 2000)

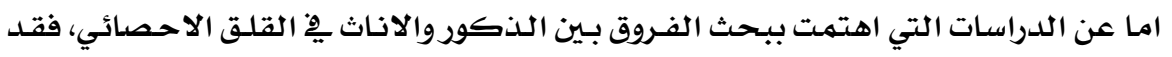

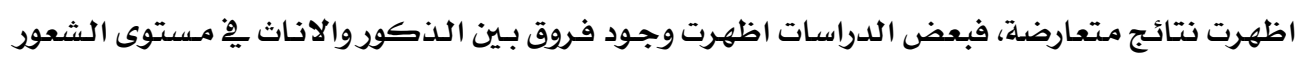
بالقلق الاحصائي لمصلحة الاناث كدراسـات (Benson, \& Eylath, 1994; Hong,1999)

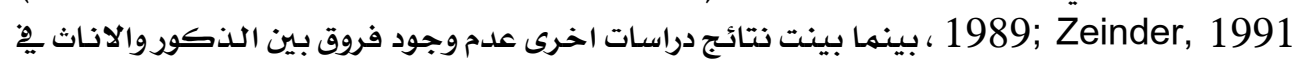


(Sutarso, 1992; Toto, 1992; Trimarco, 1997; مستوى القلق الاحصائي كدراسـات

.Baloglu, 2003)

\section{موقع اللدراسة الحالية من اللدراسات السابقة :}

ِِّْ ضوء مـا سبق فان الدراسـة الحالية لا تقل أهمية عن الدراسـات السابقة للأسباب التالية:

ا ـ نـدرة الدراسـات ذات الـصلة بموضـوع البحـث الحسالي على الـصعيدين العربـي والعـالمي ووجـود

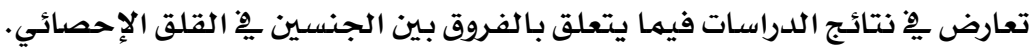

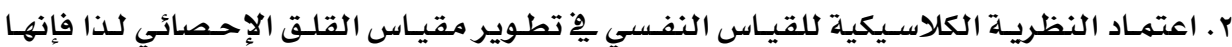

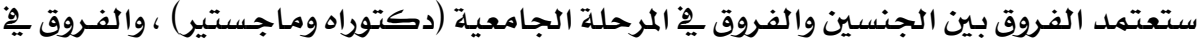

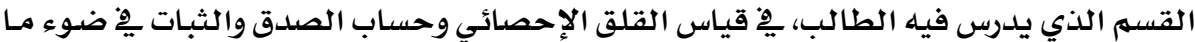

جاءت بـه هذه النظرية.

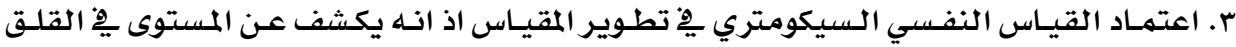

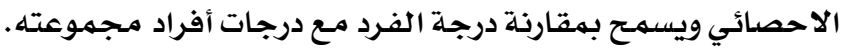

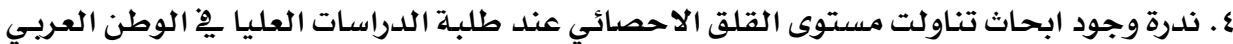
بشكل عام والاردن بشكل خاص.

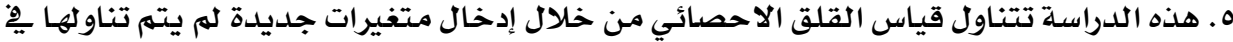

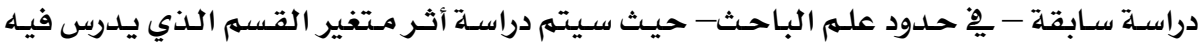

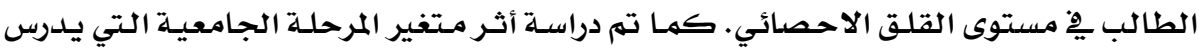

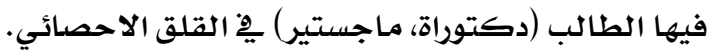

\section{الطريقة والإجراءات}

\section{مجتمع الدراسة:}

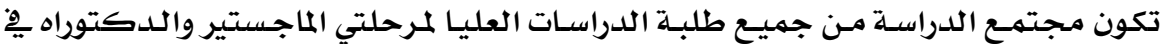

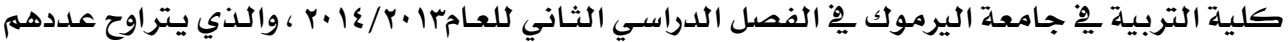

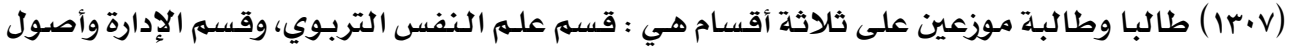

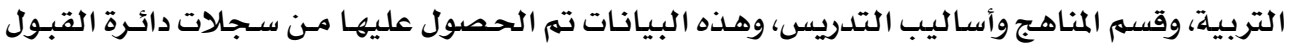
والتسجيل ِِّ جامعة اليرموك .

عينة الدراسة:

للوصول إلى الهدف المرسوم للدراسـة والذي يتمثل ِِّ دراسـة مستوى القلق الاحصائي لـدى

طلبة الدراسـات العليا ِِِ كلية التربية ِِِ جامعـة اليرموك، تم تحديد العينـة باختيـار طلبـة الدراسـات

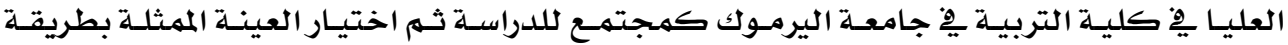
عشوائية. وذلك لسهولة الوصول إليها حيث توزعت العينات على النحو التالي: 
ا - عينة الدراسة الاستطلاعية أو التجريبية للأداة :

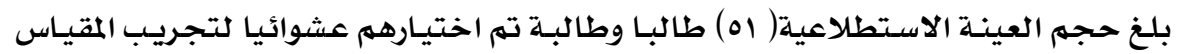

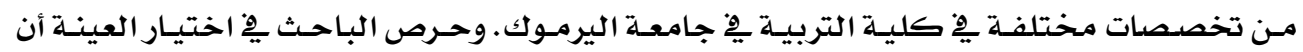

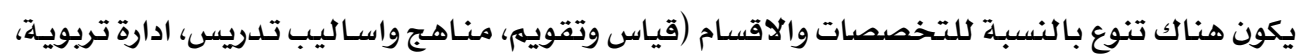

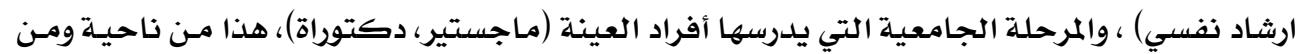

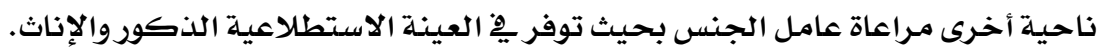

\section{r}

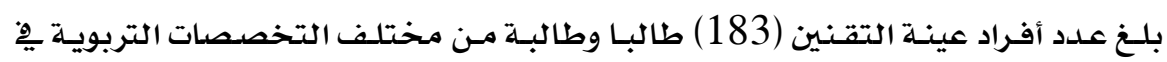

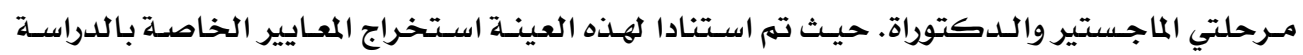

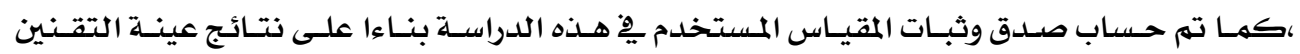
والجدول التالي يبين توزيع أفراد العينة حسب الجنس والقسمى والمستوى الدراسي:

جدول ا: توزيع أفراد عينة التقنين حسب متغيرات الدراسة

\begin{tabular}{|c|c|c|c|c|}
\hline \multicolumn{3}{|c|}{ المستوى - المي } & \multirow{2}{*}{ القسم } & \multirow[t]{2}{*}{ الجنس } \\
\hline المجموع & ماجستير & دكتوراه & & \\
\hline 32 & 19 & 13 & علم النفس التربوي والارشاد & \multirow{4}{*}{ ذكر } \\
\hline 28 & 11 & 17 & المناهج واساليب التدريس & \\
\hline 30 & 13 & 17 & الادارة التربوية واصول التربية & \\
\hline 90 & 43 & 47 & المجموع & \\
\hline 41 & 34 & 7 & علم النفس التربوي والارشاد & \multirow{4}{*}{ أثىى } \\
\hline 21 & 13 & 8 & المناهج واساليب التدريس & \\
\hline 31 & 17 & 14 & الادارة التربوية واصول التربية & \\
\hline 93 & 64 & 29 & المجموع & \\
\hline
\end{tabular}

أداة الدراسة : مقياس تقدير القلق الإحصائي (Statistical Anxiety Rating Scale (STARS:

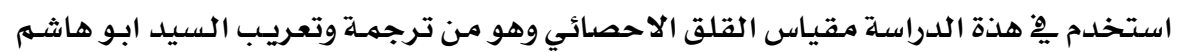

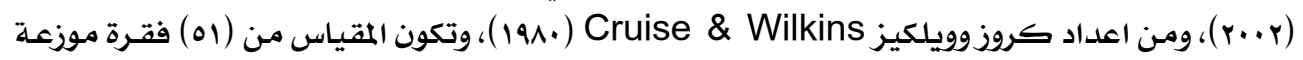

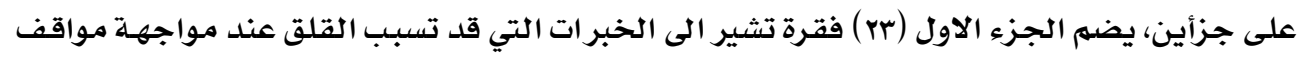

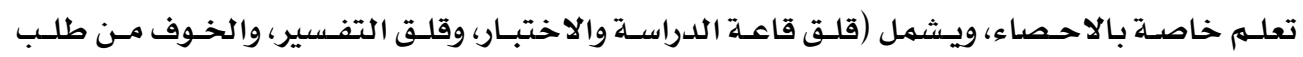

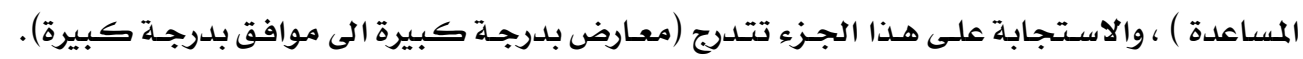

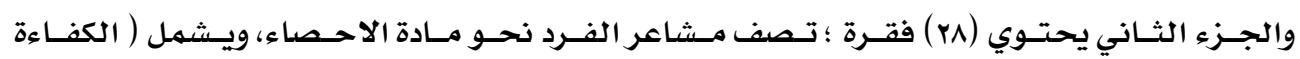

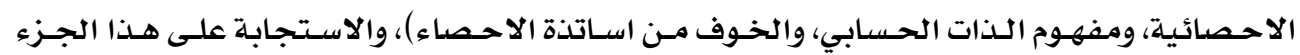

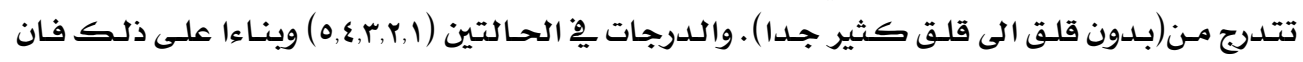


درجـة المفحوص على المقياس تتراوح بين Yro كححد أعلى واه كحسد أدنى بحيث كلمـا ارتفعت درجـة

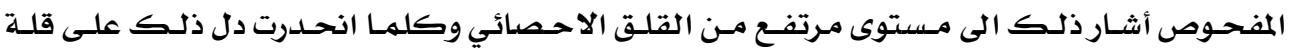

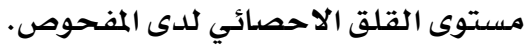
ثبات المقياس:

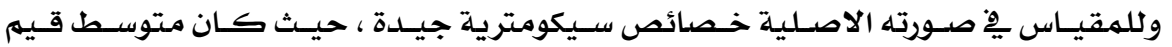

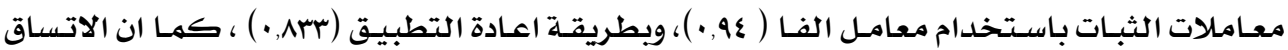

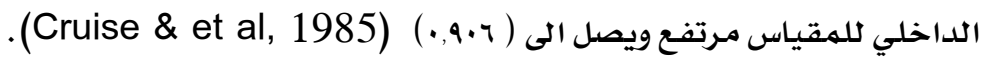
صدق المقياس : امـا عن صـدق المقيـاس فهنـاك الكثير مـن الأدلـة التي تشير الى توافر صـدق جيـد للمقيـاس.

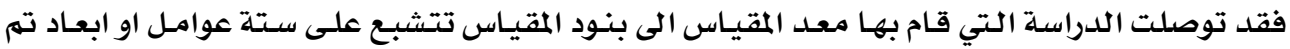

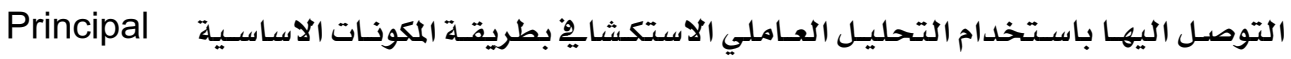

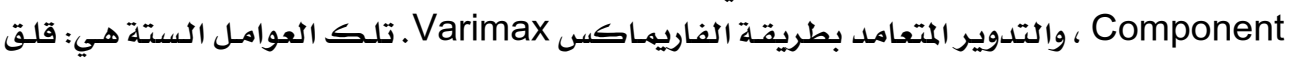

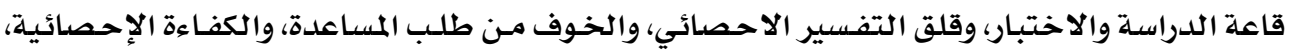
ومفهوم الذات الحسابي، والخوف من أساتذة الإحصاء.

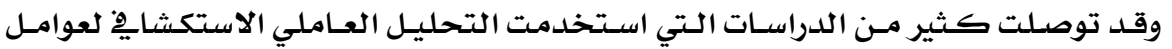

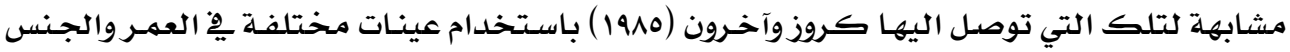
والجنسية ومستوى التعليم

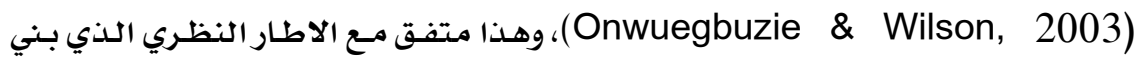

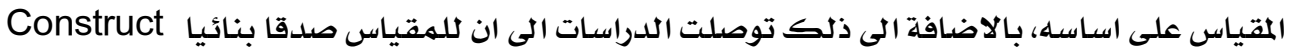
Discriminatory Validity (Onwuegbuzie, 2004) Validity .(Onwuegbuzie \& et al, 2000; Baloglu, 2003)

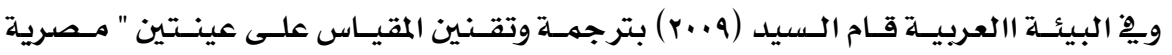

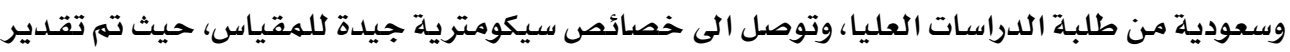

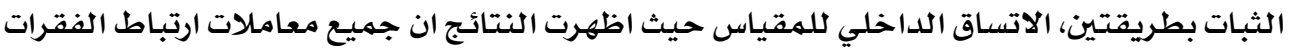

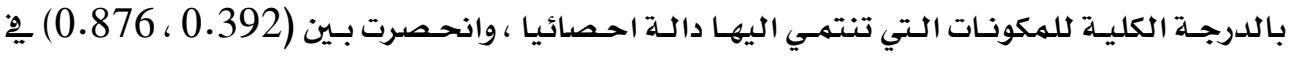

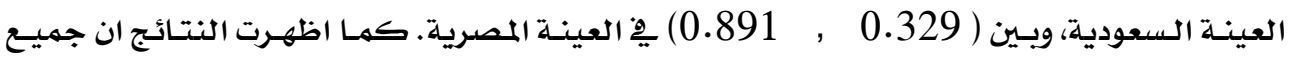

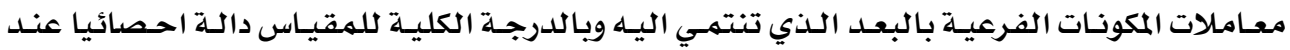
مستوى (0.01) معاملات المكنات

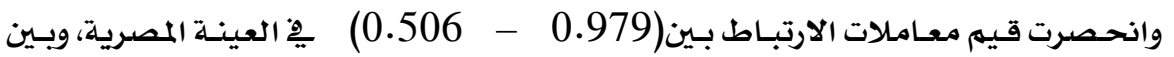

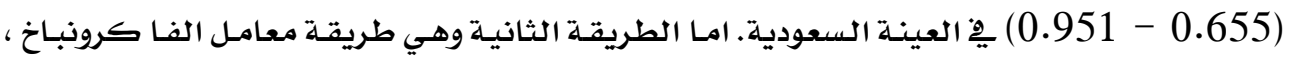

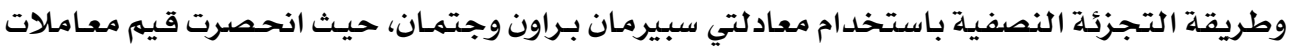




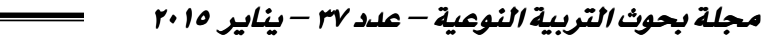

الثبـات للمكونـات الفرعيـة وللمقيـاس ككل بـين (0.602 - 0.938) يِّ العينـة المصريـة ، وبـين

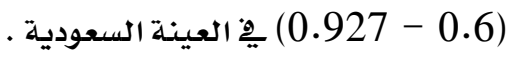

\section{تطبيق المقياس وتجريبه أوليا}

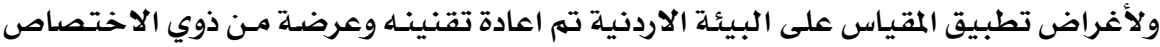

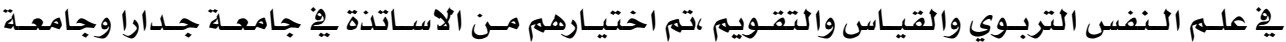

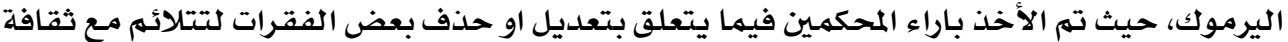

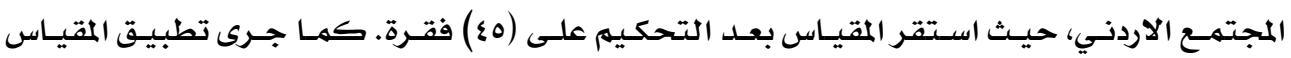

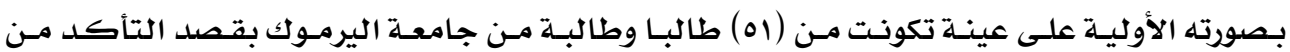

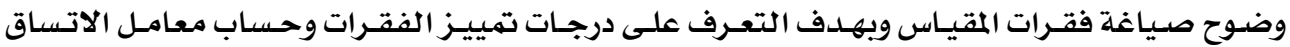

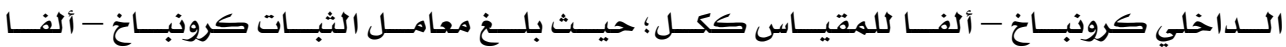

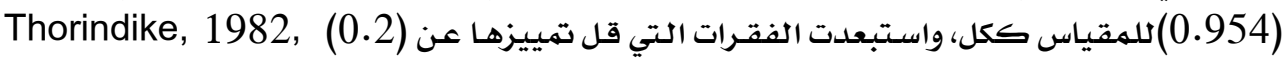

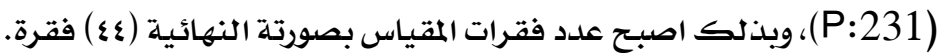
تطبيق المقياس المعلد بصورته النهائية :

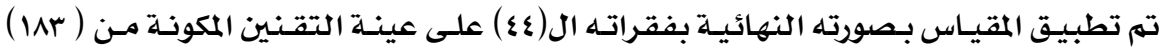
طالبـا وطالبـة كمها سبق الاثـارة لـذلك. أدخلـت البيانـات الى ذاكـرة الحاسـوب ليصار الى تحليلـها

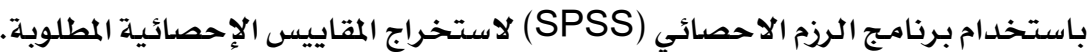
1. ثبات المقياس:

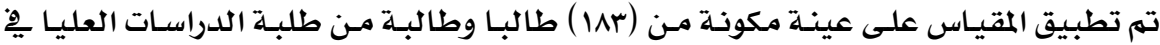

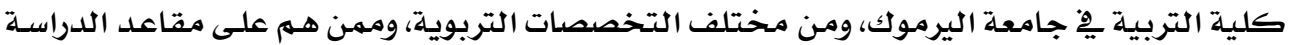

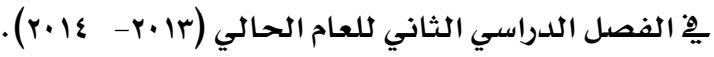

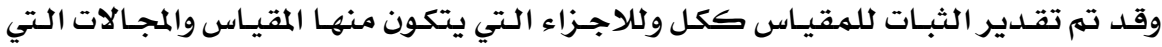

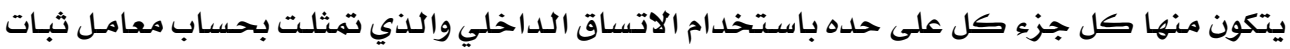

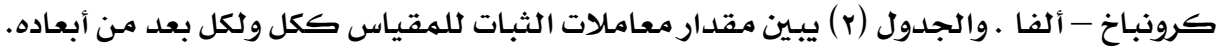
جدول ب: نتائج تطبيق معادلة (كرونباخ الفا) على جميع مجالات مقياس القلق الإحصائي والمقياس ككل

\begin{tabular}{|c|c|c|}
\hline معامل الثبات & عدد الفقرات & الجزء ومجالاته \\
\hline 0.945 & $r$ & () الخبرات التي تسبب القلق \\
\hline 0.892 & $\Lambda$ & أ) قلق قاعة الدراسة والاختبار \\
\hline 0.902 & 11 & ب) قلق التفسير \\
\hline 0.789 & $\varepsilon$ & ج) الخوف من طلب المساعدة \\
\hline 0.944 & $r$ & r) الشاعر نحو الاحصاs \\
\hline 0.926 & 1. & أ أهمية الاحصاء \\
\hline 0.831 & $r$ & ب) مفهوم الذات الحسابي \\
\hline
\end{tabular}




\begin{tabular}{|c|c|c|}
\hline 0.751 & $\varepsilon$ & ج) الخوف من اساتذة الاحصاء \\
\hline 0.964 & $\leqslant \varepsilon$ & المقياس ككل \\
\hline
\end{tabular}

واظهـرت نتائج التحليـل الاحسصائي أن معامـل الثبـات الكلـي للمقيـاس مرتفـع ( 9 9. • ) مهـا

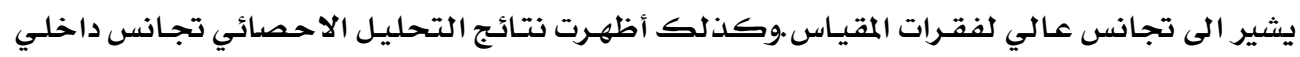

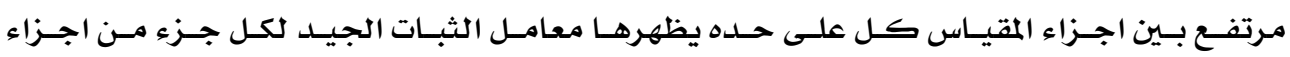

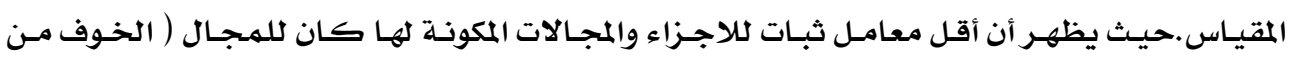

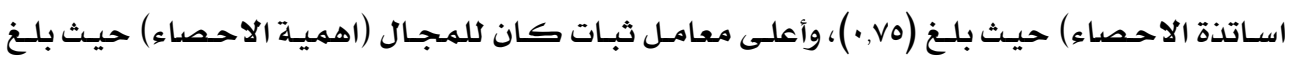

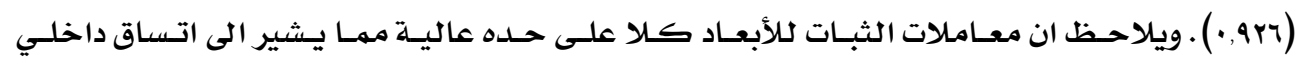
للمقياس وتجانس بين فقرات الأبعاد.

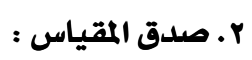

فقد تم تحري دلالات الصدق من خلال :

1 - الصدق الظاهري : تم عرض المقياس يْ صورته الاولية على مجموعـة مـن اسـاتذة القياس

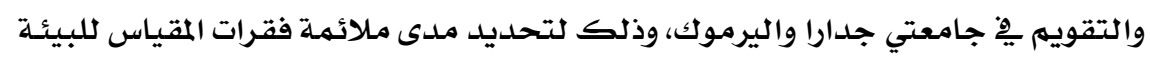

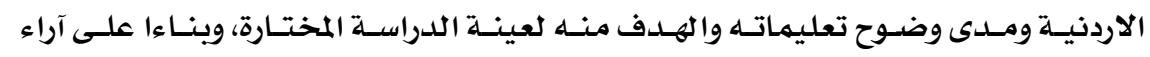

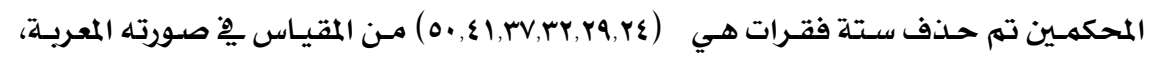

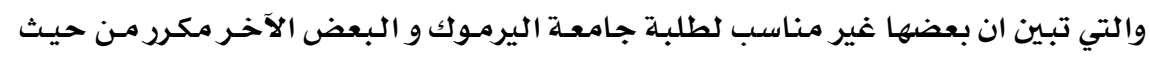

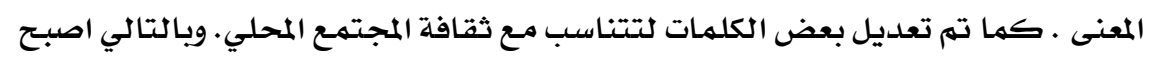

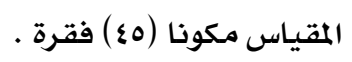

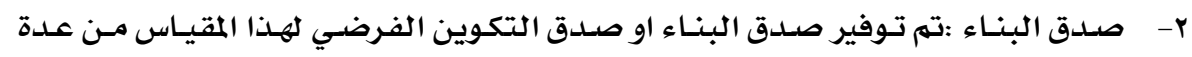

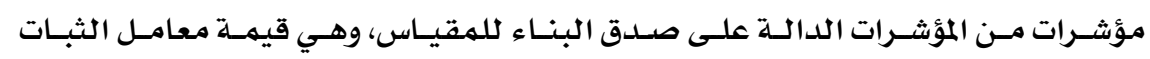

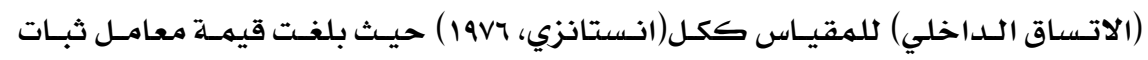

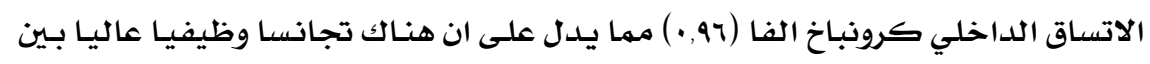

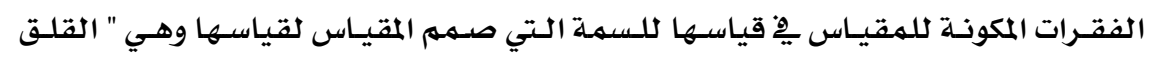

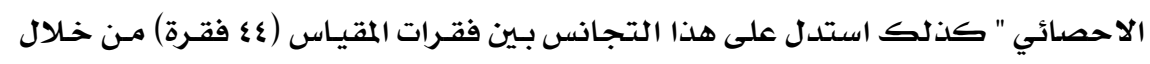

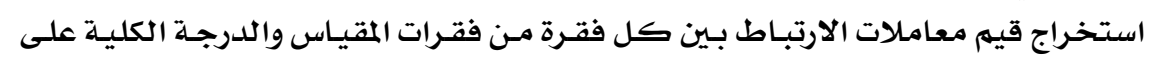

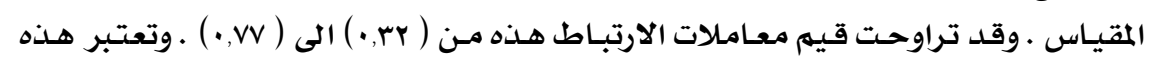

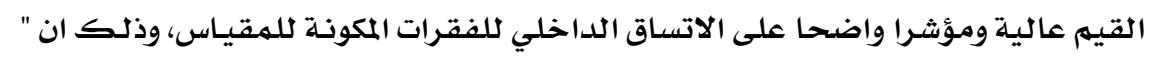

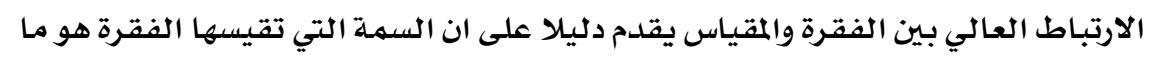

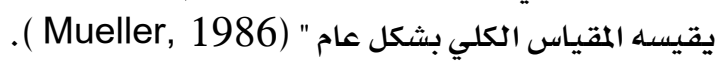

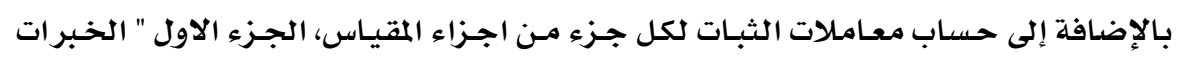

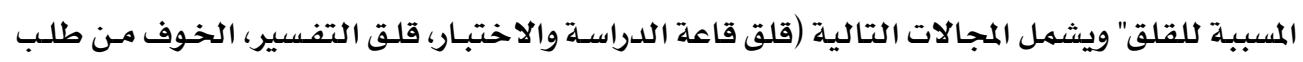

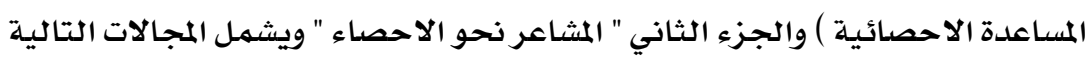




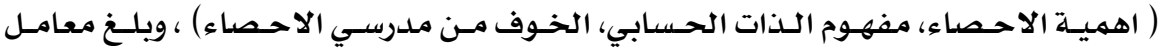

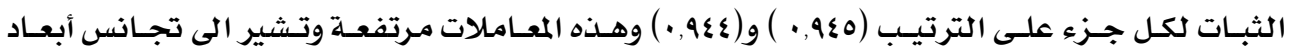

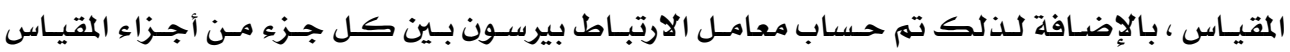

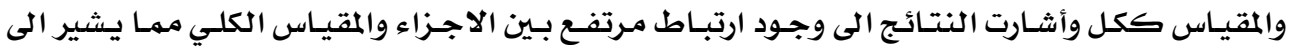

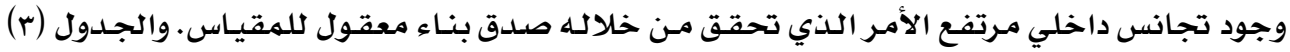
يبين معاملات الارتباط بين اجزاء اجماء المقياس والمقياس ككل.

جدول ب : معاملات الارتباط بين اجزاء المقياس والمقياس ككل

\begin{tabular}{|c|c|c|}
\hline الدلالة الإحصائية & معامل الارتباط & الجزي \\
\hline$\cdot, \cdot \cdot$ & 0.922 & الخبرات المسببة للقلق \\
\hline$\cdot, \cdot \bullet$ & 0.921 & المشاعر نحو الاحصاء \\
\hline
\end{tabular}

المعالجة الإحصائية:

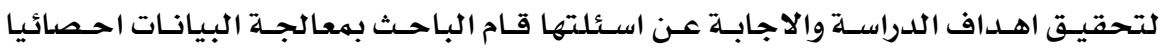

عن طريق:

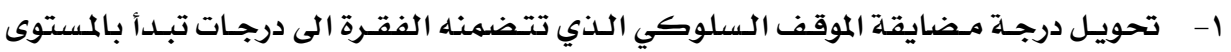

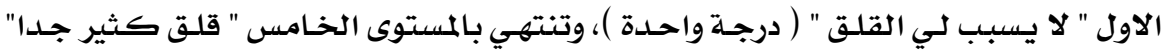

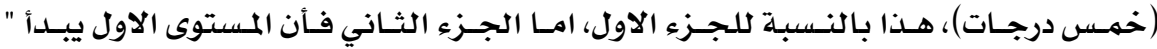

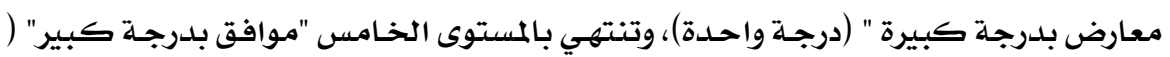

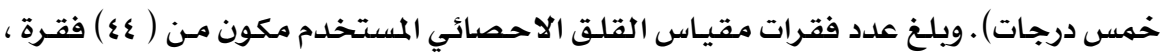

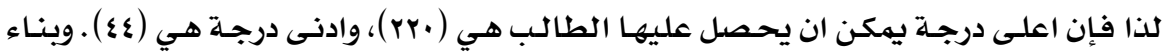

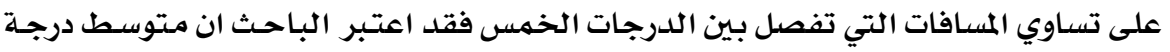

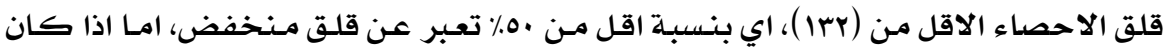

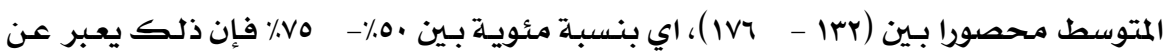

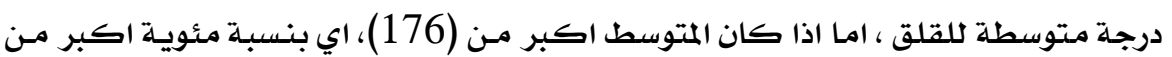

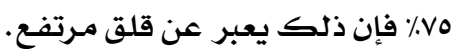

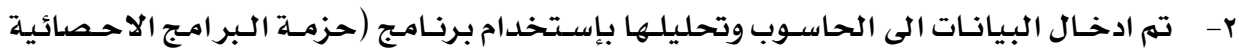

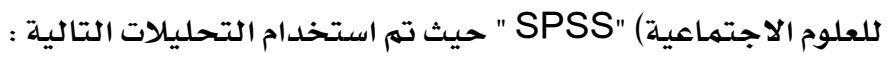

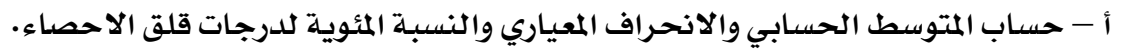
ب - معامل الارتباط.

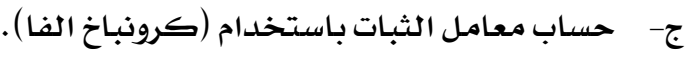

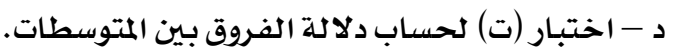
ه- مليل التباين الاحادي. 


\section{أولا : النتائج المتعلقة بالإجابة على السؤال الأول}

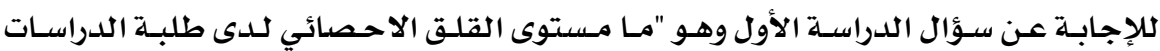

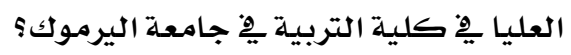

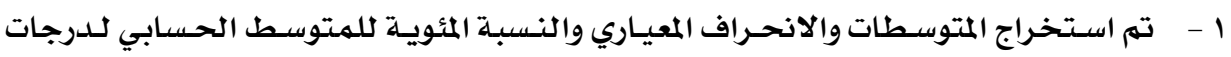

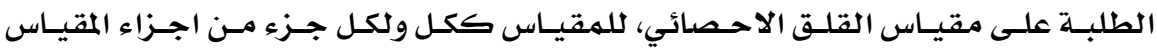

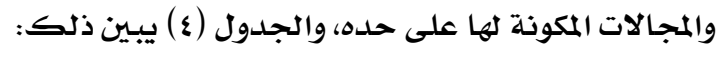

جدول \& : المتوسطات الحسابية والانحرافات المعيارية والنسبة المئوية للمتوسط الحسابي

لقلق الاحصاء عند الطلبـة

\begin{tabular}{|c|c|c|c|}
\hline النسبة المئوية & الانحراف المعياري & المتوسط الحسابي & علد الطلبة \\
\hline$\% 47.8$ & 33.755 & 117.13 & MT \\
\hline
\end{tabular}

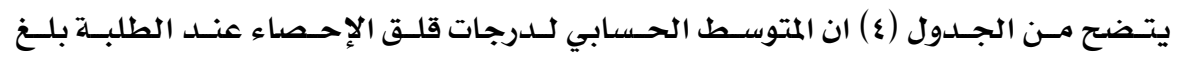

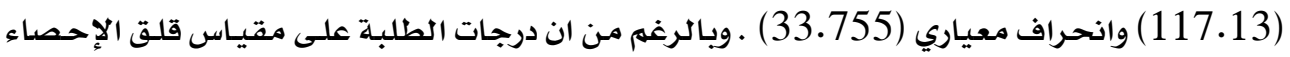

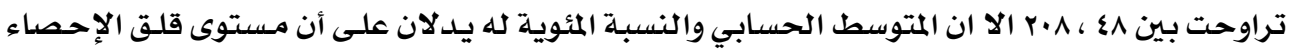

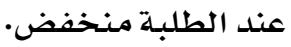

ثانيا : النتائج المتعلقة بالإجابة على السؤال الثاني:

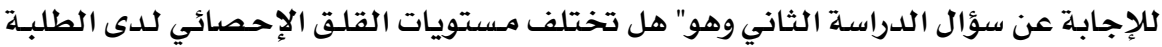

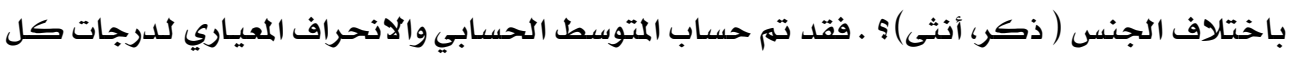

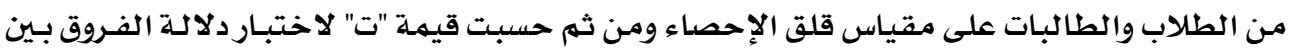

المتوسطات ويتضح من خلال الجدول(ه ) :

جدول ه: المتوسطات الحسابية والانحرافات المعيارية وقيمة ت لدرجات الطلاب والطالبات

على مقياس قلق الإحصاء

\begin{tabular}{|c|c|c|c|c|c|}
\hline مستوى الدلالة & قيمة ت & الانحراف المعياري & المتوسط الحسابي & العدد & الجنس \\
\hline \multirow[t]{2}{*}{.036} & -2.113 & 29.598 & 111.82 & 9. & ذكر \\
\hline & & 36.774 & 122.27 & 94 & أثثى \\
\hline
\end{tabular}

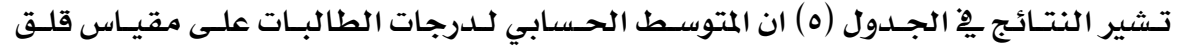

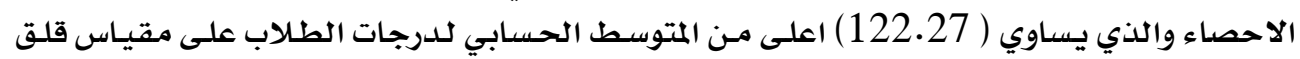

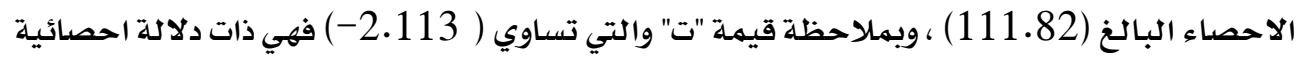

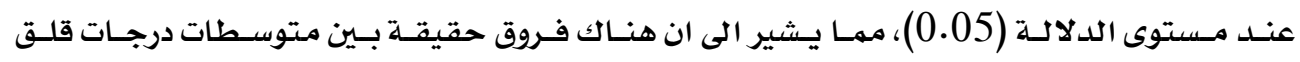
الاحصاء بـين الطلاب والطالبات لصالح الطالبات. 
ثالثا : النتائج المتعلقة بالإجابة على السؤال الثاث

للإجابة عن سؤال الدراسـة الثالث وهو:" هل تختلف مستويات القلق الاحصدائي لـدى الطلبـة

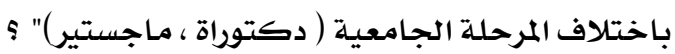

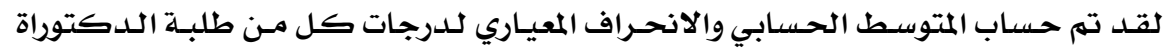

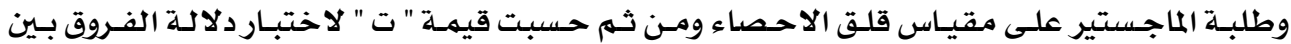

المتوسطات ويتضح من خلال الجدول (ج) :

جدول ج: المتوسطات الحسابية والانحرافات المعيارية وقيمة ت لدرجات

طلبة الدكتوراة والماجستير على مقياس قلق الاحصاء

\begin{tabular}{|c|c|c|c|c|c|}
\hline مستوى الدلالة & قيمة ت & الانحراف المعياري & المتوسط الحسابي & العدد & المرحلة الجامعية \\
\hline \multirow[t]{2}{*}{0.583} & 0.55 & 37.389 & 118.76 & vi & الدكتوراة \\
\hline & & 31.048 & 115.97 & $1 . v$ & الماجستير \\
\hline
\end{tabular}

تشير النتائج يِ الجدول (ج) ان المتوسط الحسابي لدرجة طلبة الدكتوراة على مقياس قلق

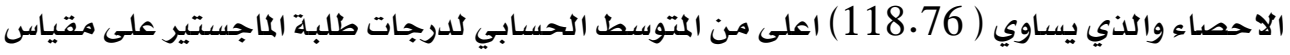

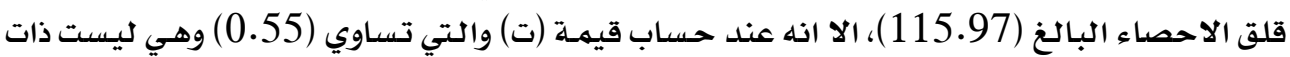

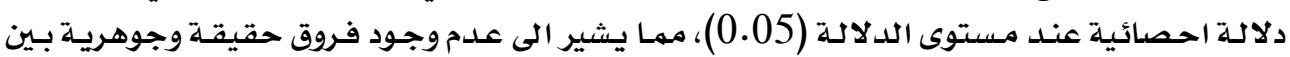

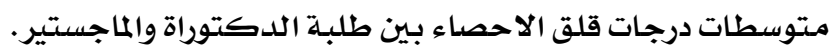
رابعا : النتائج المتعلقة بالإجابة على السؤال الرابع:

للإجابة عن سؤال الدراسة الرابع وهو: هل تختلف مستويات القلق الاحصـائي للدى الطلبـة باختلاف التخصص (القسم) ( قسهم علهم النفس التربوي، قسم المناهج واساليب التدريس، قسهم الادارة التربوية واصول التربية ) ؟ باخداف التخصن

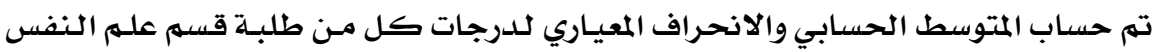

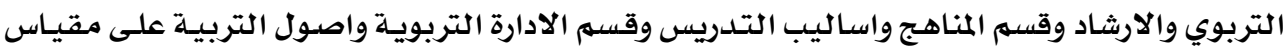

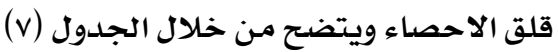
جدول V : المتوسطات الحسابية والانحرافات المعيارية تبعاً لمتغير القسهم

\begin{tabular}{|c|c|c|c|c|c|c|}
\hline \multicolumn{2}{|c|}{ الادارة التزبوية واصول التربية } & \multicolumn{2}{|c|}{ المناهج واساليب التدريس } & \multicolumn{2}{|c|}{ علم النفس التربوي والارشاد } & \multirow[b]{2}{*}{ 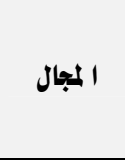 } \\
\hline الالمعراف & الحتوسط & الالمعراف & المتوسط & الالمعياري & الحتوسط & \\
\hline 31.570 & 138.54 & 23.135 & 105.98 & 33.318 & 106.73 & المقياس ككل \\
\hline
\end{tabular}

تشير النتائج مِّ الجـدول (v) ان المتوسط الحسابي لدرجـة طلبـة قسهم علدم النفس التربوي

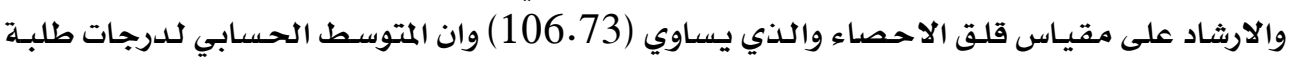


المنـاهـج واسـاليب التـدريس (105.98) بينمـا كـان المتوسـط الحسـابي لقسم الادارة التربويـة واصـول التربية (138.54).

وللكشف عن الفروق يِّ مستوى القلق الاحصائي بـين أفراد العينـة مهـن يدرسـون يِّ الاقسـام

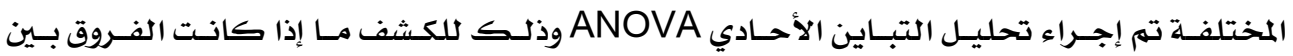

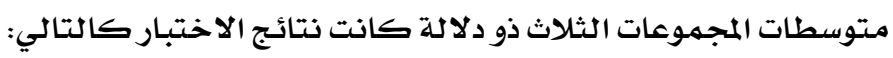
جدول ^ : تحليل التباين الأحادي (ANOVA) للفروق بين المتوسطات الحسابية لدرجات الطلبة على مقياس قلق الاحصاء تبعا لمتغير التخصص ( القسم )

\begin{tabular}{|c|c|c|c|c|c|}
\hline مستوى الدلالة & قيمة (ف) & متوسط المربعات & درجات الحرية & مجموع المربعات & مصدر التباين \\
\hline \multirow[t]{3}{*}{.000} & 22.828 & 20979.102 & 2 & 41958.205 & بين المجموعات \\
\hline & & 918.992 & 180 & 165418.648 & داخل المجموعات \\
\hline & & & 182 & 207376.852 & المجموع \\
\hline
\end{tabular}

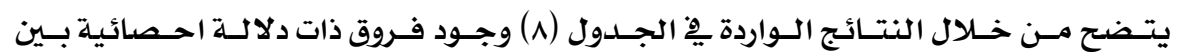

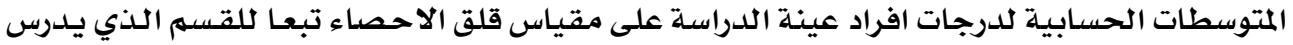

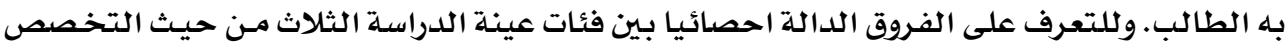

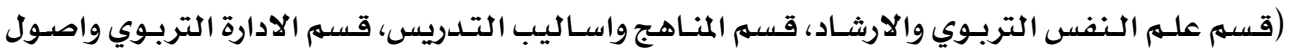

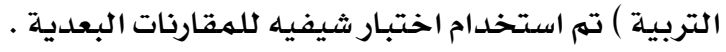

جدول 9 : دلالة الفروق بين المتوسطات الحسابية لمجموعات الطلبة على مقياس قلق الاحصاء تبعا للقسهم

\begin{tabular}{|c|c|c|c|}
\hline الادارة التربوية واصول التربية & المناهج واساليب التدريس & علم النفس التربوي والارشاد & القسم \\
\hline 138.54 & 105.98 & 106.73 & الوسط الحسابي \\
\hline$-31.815^{*}$ & .746 & - & علم النفس التربوي والارشاد \\
\hline$-32.561^{*}$ & - & - & المناهج واساليب التدريس \\
\hline- & - & - & الادارة التربوية واصول التربية \\
\hline
\end{tabular}

* ذات دلالة احصائية عند (0.05)

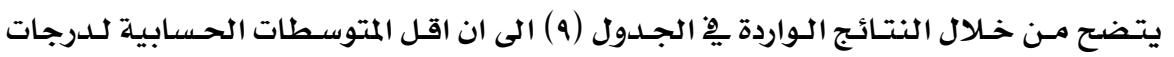

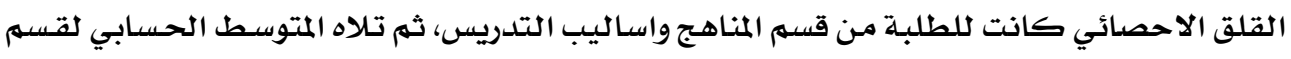

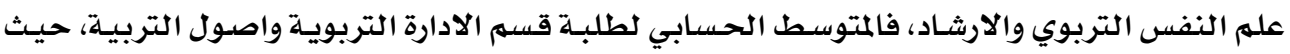

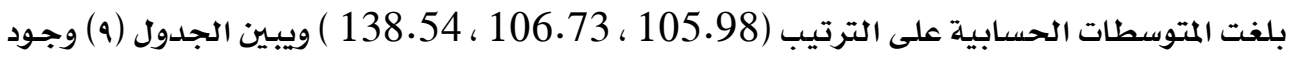

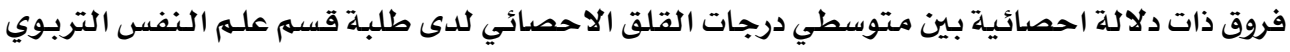

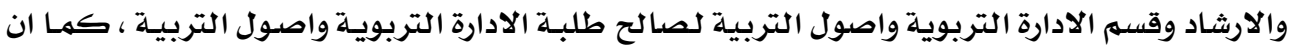

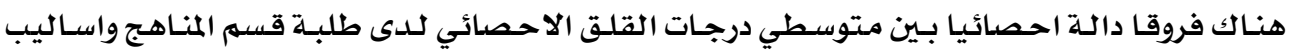


مجلة بحوث التربية النوعية - علددrr - بيناير 10 ب م

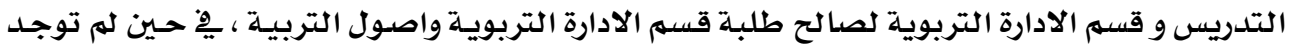

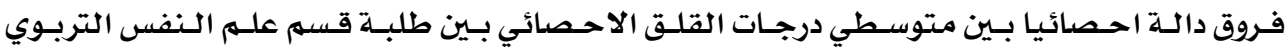
والارشاد وطلبة قسهم المناهج واسـاليب التدريس.

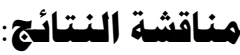

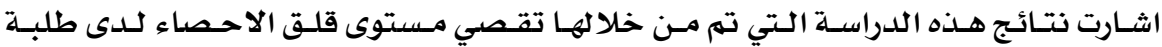

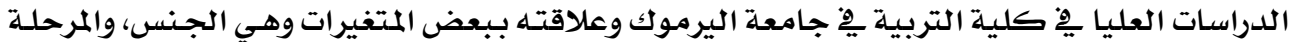

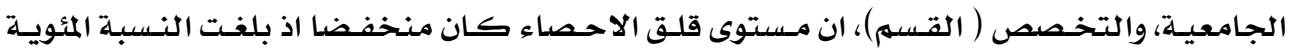

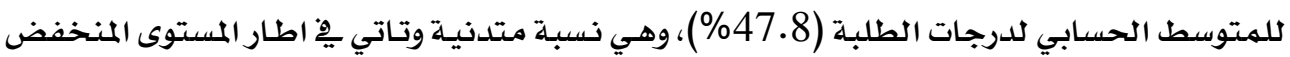

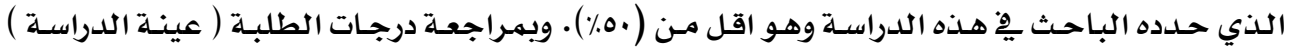

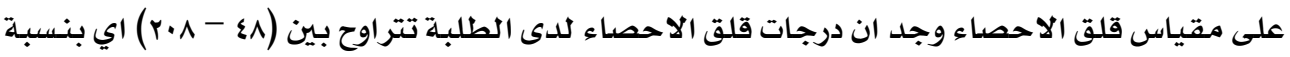

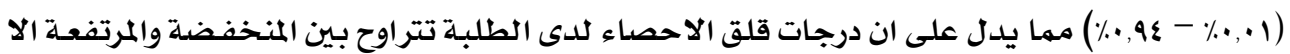

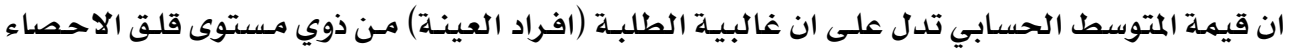

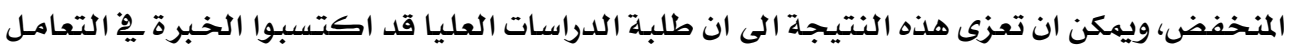

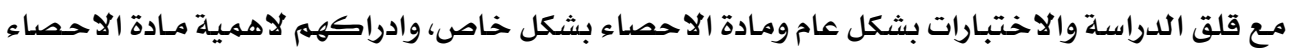

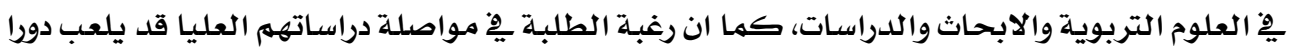

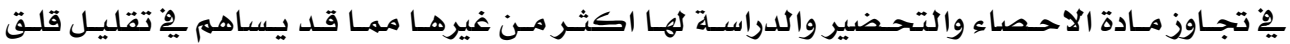

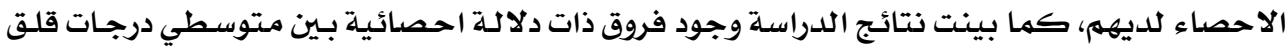

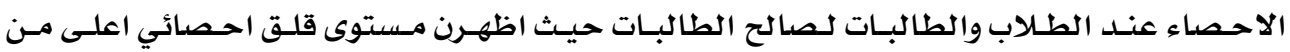

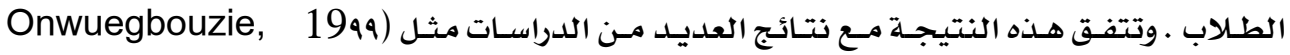

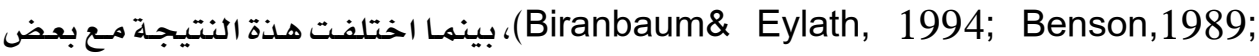

الدراسات مثل (Toto, 1992; Trimarco, 1997; Baloglu, 2003).

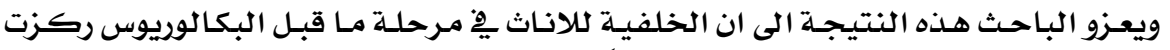

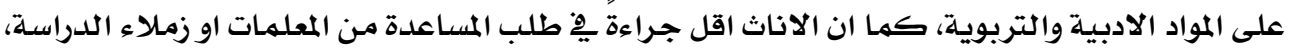

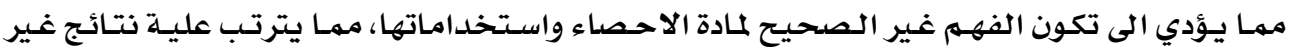
مقبولة عند القيام بالتحليل والتفسير الاحصئ فئئي.

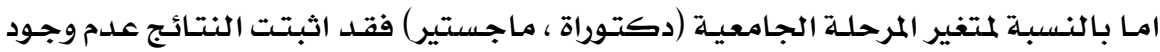

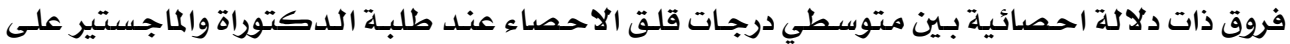

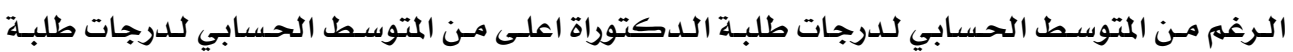

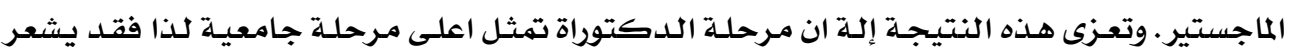

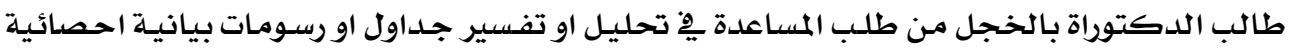

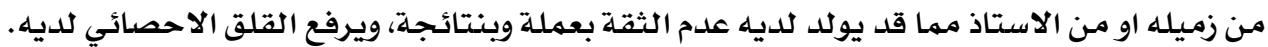




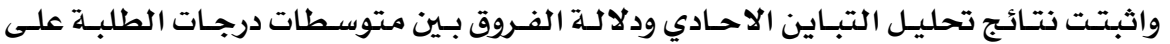

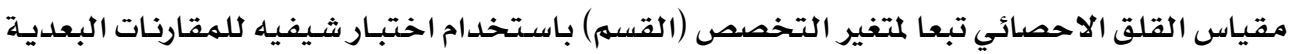

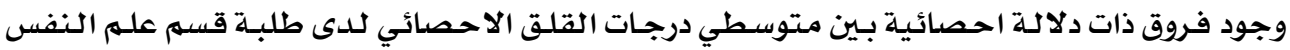

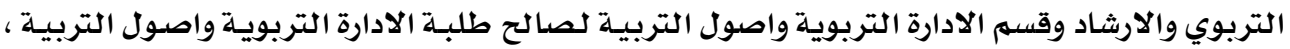

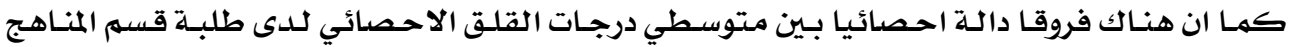

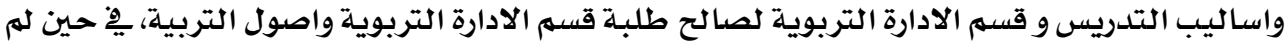

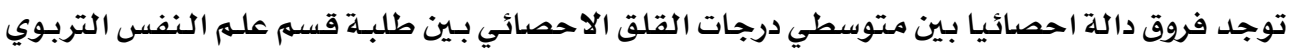

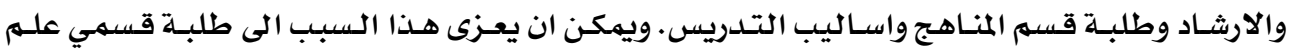

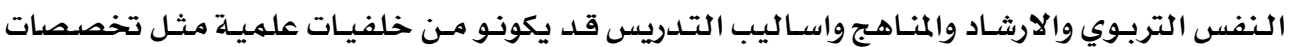
القياس والتقويهم ِِّ قسم علهم النفس التربوي والارشاد وتخصص اسـاليب تـدريس الرياضيات والعلوم

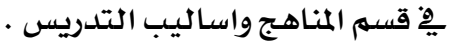

التوصيات والاقتزحات:

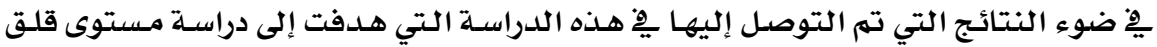

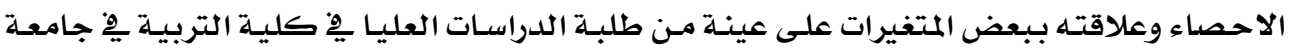

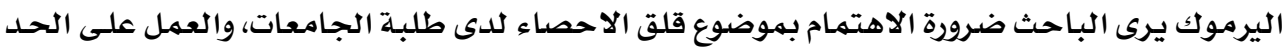

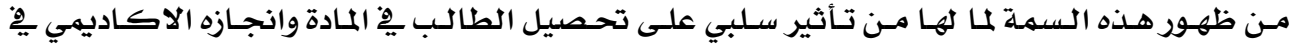

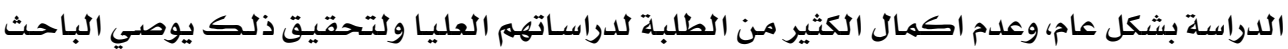
بما يلي :

ا- تطبيق المقياس على جامعات أخرى من الجامعات الحكومية والخاصة .

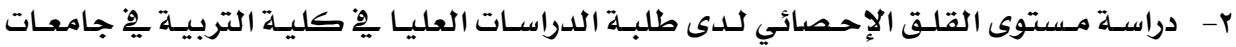

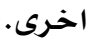

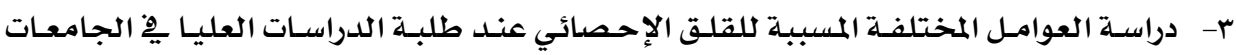

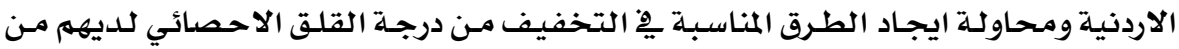

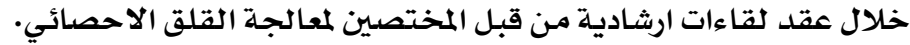

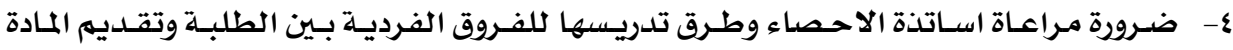

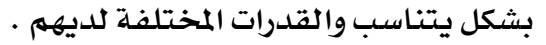

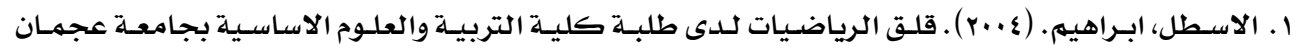

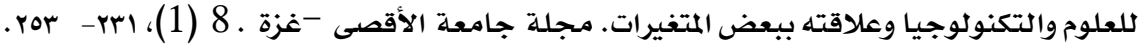

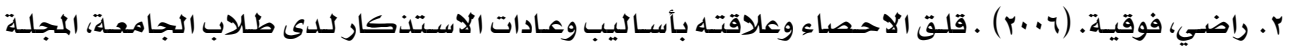

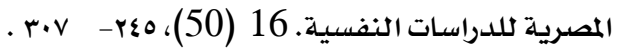




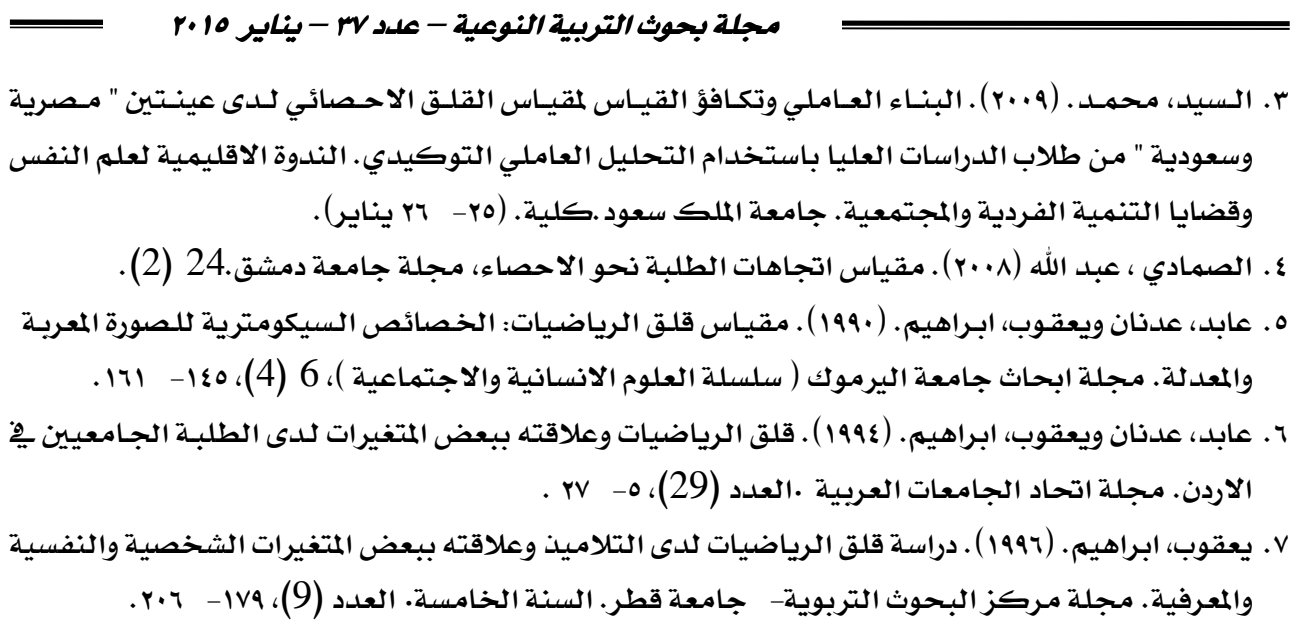

8. Baloglu, M. (2003). Individual Differences in Statistics Anxiety Among College Student, Personality and Individual Differences, 34(5) ,pp.855-865

9. Bell , j. (2003). Statistics Anxiety: The Nontraditional Student, ducation, 124(1),pp.157-162.

10. Benson , J. (1989) . Structural Components of Statistical Test Anxiety in Adults: An Exploratory Model , Journal of Experimental Education,

11. 57(3), pp.247-261.

12. Br Bradstreet, T. (1996). , "Teaching Introductory Statistics Courses So That Nonstatisticians Experience Statistical Reasoning. "American Statistician, 50(1), 69- 78.

13. Cleg, F. (1982). Simple Statistics. Cambridge: Cambridge University Pres.

14. Collins, K \& Onwuegbuzie, A. (2007). Relationship Between Reading Ability and Statistics Anxiety Among African - American Graduate Students: Implications For The Teaching and Learning of Statistics, I Cots , 7,1-4.

15. Cruise, R, Cash , W and Bolton, D. (1985). Development and of Instrument To Measure Statistical Anxiety, Proceeding of the American Statistical Association, pp.92-96.

16. Hong, E. (1999). Effects of Gender, Math Ability, Trait Test Anxiety Statistics Course Anxiety, Statistics Achievement and Perceived Test Difficulty on State Test Anxiety, Paper Presented at the Annual Meeting of the American Educational Research Association ( Montreal, Quebec , Canada, April 19-23) 
17. James, B. (1998). International Students Have Statistics Anxiety Too, Education , 118 (4) , pp.634-636.

18. Keable, D. (1997). The Management Of Anxiety A guide For Therapists, New York, Churchill Livingston .

19. Mji , A \& Onwuegbuzie , A. (2004) . Evidence of Score Reliability and Validity of the Statistical Anxiety Rating Scale Among Technikon Students in South Africa, Measurement \& Evaluation in Counseling \& Development , 36(4), pp.238-251.

20. Onwuegbuzie , A \& Wilson , V. (2003). Statistics Anxiety: Nature, Etiology, Antecedents, Effects and Treatments - a Comprehensive Review of the Literature, Teaching in Higher Education , 8 (2) , pp.195-209 .

21. Onwuegbuzie , A. (1997).Writing a research proposal : The role of Library anxiety : statistics anxiety and composition anxiety, Library and Information Science Research , 19,5-33.

22. Onwuegbuzie, A. (1999). Statistics Anxiety Among African American Graduate Students : an Affective filter ?, Journal of Black Psychology ,25(2), pp.189-209.

23. Onwuegbuzie, A. (2000). A Statistics Anxiety and the role of Self Perception, The Journal of Educational Research,93 (5), pp.323-335

24. Onwuegbuzie, A. (2004). Academic Procrastination and Statistics Anxiety, Assessment \& Evaluation in Higher Education, 29(1), pp.3-19.

25. Onwuegbuzie, A , Ros , D \& Ryan, J. (1997). The components of Statistics Anxiety : A Phenomenological Study, Focus on Learning Problems in Mathematics , 19(4), pp.11-35.

26. Onwuegbuzie, A ; Slate, J ; Paterson, F; Watson, M \& Schwartz, R. (2000). Factors Associated With Underachievement in Educational Research Courses, Research in The Schools , 7(1),pp.53-65.

27. Pan , W \& Tang, M. (2004). Examining the Effectiveness of Innovative Instructional Methods on Reducing Statistics Anxiety for Graduate Students in the Social Sciences, Journal of Instructional Psychology , 31(2) , pp.149-159.

28. Pan , W\& Tang, M. (2005). Students Perceptions on Factors of Statistics Anxiety and Instructional Strategies, Journal of InstructionalPsychology , 32 (3) , pp. 205-214. 
29. Schacht, S \& Stewart, B (1990). What's Funny about Statistics ? A technique for reducing student Anxiety, Teaching Sociology, 18 , 52-56.

30. Sutarso, T. (1992) . Some Variables in Relation to Students Anxiety in Learning Statistics, Paper Presented at the Annual Meeting of the Mid - South

31. Educational Research Association ( Knoxville ,TN, November 11-13 ).

32. Toto, S. (1992). Some Variables in Relation to Students Anxiety in Learning Statistics, Paper Presented at the Annual Meeting of the Mid - South Educational Research Association.

33. Trimarco , K. (1997). The effects of a Graduate Learning Experience on Anxiety Achievement and Expectations in Research and Statistics, Paper Presented at the Annual Meeting of the Northeastern Educational Research Association (28th, Ellenville, New York, October , 28-30).

34. Wilson, V \& Onwuegbuzie, A. (2001). Increasing and Decreasing Anxiety : A Study of Doctoral Students in Education Research Courses ,Paper Presented at the Annual Meeting of the Mid - South Educational Research Association (30th, Little Rock, A R, November15-16).

35. Wilson, V.A. (1996). Factors related to anxiety in statistics. Unpublished doctoral dissertation, University of Southern Mississippi, Hattiesburg.

36. Wilson , V. (1997). Factors Related to Anxiety in the Graduate Statistics Classroom, Paper Presented at the Annual Meeting of the Mid - South Educational ( Memphis, TN , November 12-14).

37. Zeidner, M. (1991). Statistics and mathematics anxiety in social science students-some interesting parallels, British Journal of Educational Psychology, 61, 319-328. 
The level of worry Indeed at the graduate students in the College of Education, The direction of Statistical materials, And its relationship with some variables

\section{Study summary}

This study aimed to identify the level of concern at the statistics graduate students in the Lord's College at Yarmouk University and its relationship to this attribute of each sex, and undergraduate, in addition to specialization (section). The study sample consisted of 183 students from the graduate students in the College of Education at Yarmouk University during the second semester of the academic Atalam 2013-2014. For purposes of this study, the researcher using a scale estimate statistical concern that has been Arabization Statistical Anxiety Rating Scale (STARS), has been amended and codified to fit with the Jordanian environment where it is applied, in its final form, which included (44) paragraph.

The results of the study showed that the level of concern at the statistics graduate students in the College of Education at the University of Yarmouk low. And showed no statistically significant differences in the level of statistical concern between the two phases of doctoral and master's differences at the level of significance (0.05) is due for university degrees, and the results showed a statistically significant differences in the level of anxiety statistical differences due to gender, in favor of females. And showed a statistically significant differences in the level of statistical concern among the three different sections differences (Department of Educational Psychology and Counseling, and the Department of Curriculum and Instruction, Department of Educational Administration and the origins of Education) for the benefit of the Department of Educational Administration and the origins of Education. 


\section{هلحق الدراسة \\ هقياس القلق الاحصائي}

السـلام عليكم ورحمة الله وبركاته

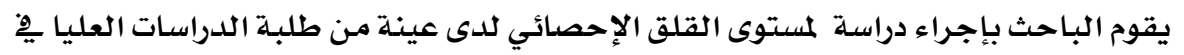

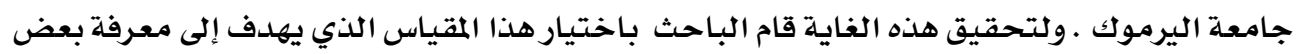

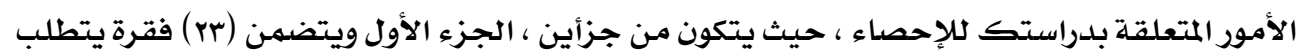

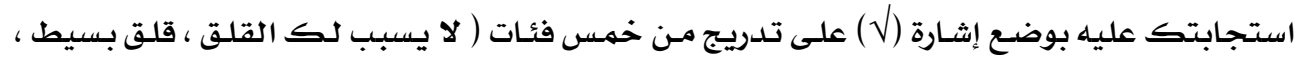

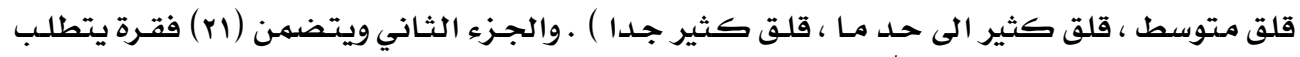

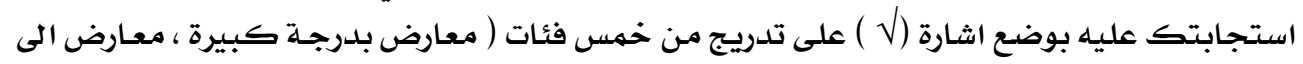

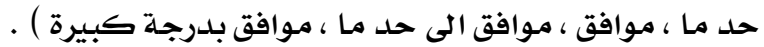

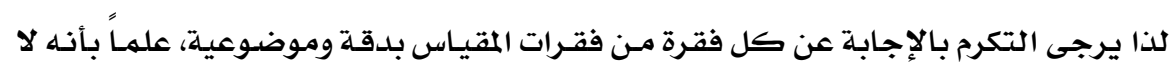

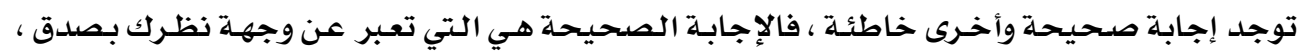

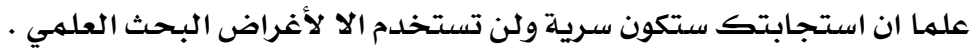
وتفضلوا بقبول فائق الاحترام .

$$
\begin{aligned}
& \text { الباحثون: } \\
& \text { د. مسله يوسف الطيطي } \\
& \text { رائد سليمان ابداح } \\
& \text { د. محي الدين فهد جرادات }
\end{aligned}
$$

\begin{tabular}{|c|c|c|}
\hline & (كلية التربية ) & جامعة اليرموك \\
\hline 口 أثى & ( & الجنس \\
\hline 口 ماجستير & 口 دكتوراه & الدرجة العلمية \\
\hline & & التخصص \\
\hline 口 ثالثة فأكثر & 口 أولى & مستوى السنة الدراسية \\
\hline
\end{tabular}

القسم الأول : البيانات العامة 
= مستوى قلق الإحصاء للى طلبة اللراسات العليا فِ مكلية التربية وعلاقته بيعض المتغيرات

*الجزs الأول: ضع إشارة ( ل ) أمام كل فقرة من فقرات الاستبانة وتحت الحالة التي تنطبق عليك

\begin{tabular}{|c|c|c|c|c|c|c|}
\hline قلق كثير & قلق كثير & قتق & قلق بسيط & لا لك يسبب القلق & 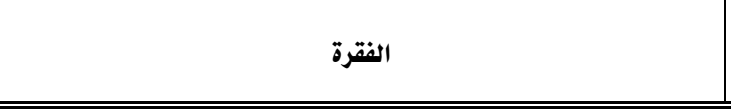 & الفقرة \\
\hline & & & & & | التحضير لامتحان مقرر الإحصاء. & .1 \\
\hline & & & & & تفسير جدول إحصائي في بحث أو دراسة علمية. & $r$ \\
\hline & & & & & | الذهاب إلى مدرس الإحصاء لطلب مساعدته في موضوع تجد صعوبة في فهمه. & $r$ \\
\hline & & & & & |أداء الواجبات أو حل التدريبات الخاصة بققرر الإحصاء & $\varepsilon$ \\
\hline & & & & & | اتخاذ قرارا إحصائي يتسم بالموضوعية على أساس البيانات التجريبية . & .0 \\
\hline & & & & & |قراءة بحث يحتوى على بعض التحليلات الإحصائية. & .7 \\
\hline & & & & & |محاولة تحديد التحليلات الإحصائية المناسبة لثروع بحث مطلوب منك. & . \\
\hline & & & & & | أداء اختبار نهائي في مقرر الإحصاء . & $\wedge$ \\
\hline & & & & & | قراءة إعلان يشتمل أشكال ورسوم بيانية. & 9 \\
\hline & & & & & |دخول قاعة الدراسة لأخذ اختبار في مقرر الإحصاء. & .1. \\
\hline & & & & & |تفسير معاني القيه الإحصائية عند مواجهتها. & .11 \\
\hline & & & & & |ترتيب البيانات لإدخالها الكمبيوتر لمعالجتها إحصائياً & ir \\
\hline & & & & & |عندما يعطى زميل آخر إجابة مختلفة للمشكلة الإحصائية التي قمت بحلها . & .14 \\
\hline & & & & & |تحديد إمكانية قبول او رفض الفرض الصفري في بحث علمي. & $1 \varepsilon$ \\
\hline & & & & & | الاستيقاظ مبكراً يوم امتحان مقرر الإحصاء. & 10 \\
\hline & & & & & عند طلب المساعدة من أستاذ الإحصاء لفهم تتائج التحليلات الإحصائية. & .17 \\
\hline & & & & & محاولة فهم أفضل البلائل الممكنة للتحقق من الفرض البحثي &. iv \\
\hline & & & & & |قراءة تتائج التحليل الإحصائي المرتبطة ببحث لأحد الزملاك . & .11 \\
\hline & & & & & طلب مساعدة من شخص ما لديه خبرة بالتحليلات الإحصائية ليفهكك تتائج إحصائية & .19 \\
\hline & & & & & |محاولة فهم التحليلات الإحصائية الموجودة في بحث علي. & r. \\
\hline & & & & & عند اختيارك لمقرر الإحصاء للدراسته. & $r$ \\
\hline & & & & & مراجعة اختبار نهائي في الإحصاء عقب إعلان النتائج. & $r$ \\
\hline & & & & & |عند سؤال زميل اكبر منك لديه خبرة في الإحصاء. & . \\
\hline
\end{tabular}




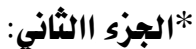

\begin{tabular}{|c|c|c|c|c|c|c|}
\hline بلدرجة & موافى حد & 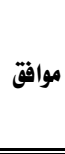 & معارض & بدربة & 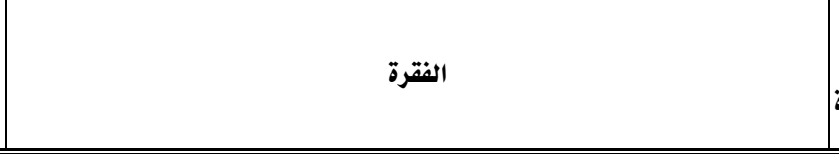 & | رقترة| \\
\hline & & & & & | الإحم أدرس الرياضيات ـ لمدة طويلـة ، وأعـرف إنـني سأواجه مشكلات بالنسبة لتقـلدمي في مقرر| & 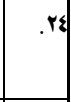 \\
\hline & & & & & |أتساكل لماذا تتعلم كل هذه في مقرر الإحصاء ولن نستخدمها في حياتنا العملية . & ro \\
\hline & & & & & | تخضصي لا يحتاج إليها . &.$r 7$ \\
\hline & & & & & | الإحصاء يأخذ مني وقتاً أكبر لقلة كفاءتي الإحصائية. & $\mathrm{rr}$ \\
\hline & & & & & |أساتذة الإحصاء مختصرون في شرحهم . & . \\
\hline & & & & & لا أستطيع فهم أبسط المعلومات الإحصائية الأساسية مما يعرقل اجراء اي تحليلات الاحصائية. & ra \\
\hline & & & & & | عشت حياة طويلة بلدون معرفة بالإحصاء لماذا يجب على تعلمه الآن & r. \\
\hline & & & & & | له استمتع ابدا بالرياضيات ولا ادري كيف سأستمتع بالاحصاء. & .ri \\
\hline & & & & & |الإحصاء يجب ان يكون للاشخاص الذين للديهم استعداد طبيعي لتعلم الرياضيات. & .rr \\
\hline & & & & & |ليس لدي قدرات كافية تتكنني من التقدم في تحصيل الاحصاء. & .rr \\
\hline & & & & & |أستطيع الاستمتاع بالإحصاء إذا كان مجرد علاقات رياضية بحتة. & . \\
\hline & & & & & |أتقنى إلفاء مقرر ومتطلبات الإحصاء من برنامجي الأكادييي & ro \\
\hline & & & & & أشعر بأن أساتذة الإحصاء مختلفون في طريقة شرحهم للعمليات الإحصائية. & .77 \\
\hline & & & & & |أساتذة الإحصاء أكثر توجهاً نحو الأرقام منهم نحو الأشخاص. &.$r v$ \\
\hline & & & & & | أنا لا أحب الإحصاء ، ولكني لا أستطيع تبرير ذلك & .rA \\
\hline & & & & & |أساتذة الإحصاء يتحدثون بسرعة جداً ولا تستطيع تتبعهم بنطقية & ra \\
\hline & & & & & | الأشكال والجداول الإحصائية غير مطابقة للواقع العملي & . \\
\hline & & & & & |في الواقع أن الإحصاء ليست سيئة ، ولكنها فقط تعتمد على الرياضيات & . \\
\hline & & & & & | معرفية كتعلم الإحصار الانفالية والوجدانية أكثر أهمية في مهنتي ، ولـذلك لا أريــلـ إرهـاق تفكيري بأشياء & sr \\
\hline & & & & & أنا بطؤ جداً في تفكيري بالنسبة للمعلومات الإحصائية . & . \\
\hline & & & & & |الاحصاء عملية مرهقة لتفكيري وانا لست في حاجة اليه. & .8s \\
\hline
\end{tabular}

